\title{
ARTICLE
}

Translational Therapeutics

\section{The bovine dialysable leukocyte extract IMMUNEPOTENT CRP induces immunogenic cell death in breast cancer cells leading to long-term antitumour memory}

\author{
Alejandra Reyes-Ruiz ${ }^{1}$, Kenny Misael Calvillo-Rodriguez ${ }^{1}$, Ana Carolina Martínez-Torres $\mathbb{E}^{1}$ and Cristina Rodríguez-Padilla ${ }^{1,2}$
}

\begin{abstract}
BACKGROUND: Cancer recurrence is a serious problem in breast cancer (BC) patients, and immunogenic cell death (ICD) has been proposed as a strategy to overcome this recurrence. IMMUNEPOTENT CRP (ICRP) acts as an immunomodulator and can be cytotoxic to cancer cells. Thus, we evaluated if ICRP induces ICD in BC cells.

METHODS: Immunogenicity of ICRP-induced cell death was evaluated in vitro, analysing the principal biochemical characteristics of ICD in MCF-7, MDA-MB-231 and 4T1 cells. Ex vivo, we assessed the ability of killed cancer cells (KCC) obtained from ICRP-treated 4T1 cells (ICRP-KCC) to induce DC maturation, T-cell priming and T-cell-mediated cancer cytotoxicity. In vivo, we evaluated tumour establishment and antitumour immune memory after prophylactic ICRP-KCC vaccination in BALB/C mice.

RESULTS: ICRP induced caspase-independent, ROS-dependent cell death, autophagosome formation, P-elF2a, chaperone protein exposure, CD47 loss, ATP and HMBG1 release in BC cells. Additionally, ICRP-KCC promoted DC maturation, which triggered T-cell priming and cancer cytotoxicity. Prophylactic vaccination with ICRP-KCC prevented tumour establishment and induced long-term antitumour memory in BALB/C mice, involving DC maturation in lymph nodes, CD8+ T-cell augmentation in lymph nodes, peripheral blood and tumour site and ex vivo tumour-specific cytotoxicity by splenocytes.

CONCLUSIONS: ICRP induces ICD in BC cells, leading to long-term antitumour memory.
\end{abstract}

British Journal of Cancer (2021) 124:1398-1410; https://doi.org/10.1038/s41416-020-01256-y

\begin{abstract}
BACKGROUND
Breast cancer is the most frequently diagnosed cancer and the leading cause of deaths in women. ${ }^{1}$ One of the principal pitfalls leading to the mortality of this disease is associated with distant metastasis and its ability to recur up to 20 years after diagnosis, ${ }^{2}$ these characteristics are related with the low immunogenicity of breast cancer cells, as a result of cancer cell release of immunesuppressive factors, which block the cancer-immunity cycle. ${ }^{3}$ However, it is now being proposed that with appropriate immune response stimulation, cancer cells could become immunogenic.

In this regard, several studies indicate that immunogenic cell death (ICD) is a hopeful strategy to convert cancer cells into their own vaccine, promising a long-term success of anticancer therapies relying on memory immune response induction, ${ }^{4,5}$ which could deal against high recurrence rate in breast cancer patients. It has been reported that a restricted number of chemotherapies induce ICD, for instance, breast cancer patients treated with anthracyclines (ICD inducers) showed an increment in the ratio of $\mathrm{CD} 8+\mathrm{T}$ cells over regulatory $\mathrm{T}$ cells intratumourally, and this predicts a favourable therapeutic response. ${ }^{7}$

IMMUNEPOTENT CRP (ICRP), a bovine dialysable leukocyte extract (DLE) obtained from disrupted spleen, is cytotoxic to several cancer cell lines, ${ }^{8-11}$ without affecting the viability of non-
\end{abstract}

cancer cells. ${ }^{11}$ ICRP induces ICD in the murine melanoma model B16F10, ${ }^{12}$ whereas in HeLa and MCF-7 cells, ICRP-mediated cell death involves CRT exposure, ATP and HMGB1 release, which are the principal damage-associated molecular patters (DAMPs) involved in ICD. In addition, ICRP leads to elF2a phosphorylation (P-elF2a), which indicates endoplasmic reticulum (ER) stress, an early ICD biomarker. Furthermore, ICRP has been reported to induce reactive oxygen species (ROS)-dependent autophagosome formation in HeLa and MCF-7 cells. ${ }^{13}$

ROS production, ER stress and autophagy stimulate intracellular danger signalling pathways that regulate the release of DAMPs and thus ICD. ${ }^{14,15}$ These results suggest that ICRP might induce ICD in other cancer models, as a conserved mechanism. The aim of this study was to investigate the immunogenicity of ICRP-induced cell death in a panel of breast cancer models, using human and murine cell lines, as well as ex vivo and in vivo experiments using $\mathrm{BALB} / \mathrm{c}$ mice.

\section{METHODS}

Cell culture

MCF-7 human breast adenocarcinoma (ATCC ${ }^{\circledR}$ HTB-22TM), MDAMB-231 triple-negative breast adenocarcinoma (ATCC ${ }^{\circledR}$ HTB-26TM)

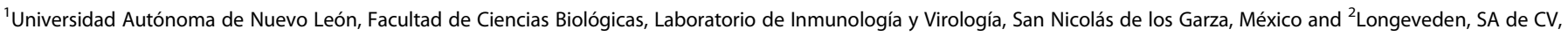
Monterrey, México

Correspondence: Ana Carolina Martínez-Torres (ana.martinezto@uanl.edu.mx)

These authors contributed equally: Alejandra Reyes-Ruiz, Kenny Misael Calvillo-Rodriguez

Received: 5 March 2020 Revised: 1 December 2020 Accepted: 16 December 2020

Published online: 3 February 2021 
and 4T1 murine mammary adenocarcinoma (ATCC ${ }^{\circledR}$ CRL2539TM) cell lines were obtained from the American Type Culture Collection. MCF-7 and MDA-MB-231 cells were cultured in DMEM-F12 supplemented with $10 \%$ foetal bovine serum (FBS) and $1 \%$ penicillin-streptomycin (complete DMEM), and $4 \mathrm{~T} 1$ cells were cultured in RPMI-1640 supplemented with 10\% FBS and 1\% penicillin-streptomycin (complete RPMI) (Life Technologies, Grand Island, NY) and routinely grown in plastic tissue-culture dishes (Life Sciences, Corning, NY). All cell cultures were maintained in a humidified incubator in $5 \% \mathrm{CO}_{2}$ at $37^{\circ} \mathrm{C}$. Cell count was performed in a Neubauer chamber, using $0.4 \%$ trypan blue (MERCK, Darmstadt, Germany).

\section{Animals}

The Animal Research and Welfare Ethics Committee (CEIBA), of the School of Biological Sciences approved this study: CEIBA-2019-006. All experiments were conducted according to Mexican regulation NOM-062-ZOO-1999. Female BALB/c mice (six-to-eight-week-old, $20 \pm 2 \mathrm{~g}$ of weight) were provided by the animal house at the Universidad Autonoma de Nuevo Leon, Mexico. Animals were housed in plastic cages in groups of four and given seven days to acclimate to the housing facility. Environmental conditions were temperature $21^{\circ} \mathrm{C} \pm 3{ }^{\circ} \mathrm{C}$, humidity $55 \% \pm 10 \%$ and 12 -h light/dark cycle. Animals were supplied with rodent maintenance food (LabDiet, St. Louis, MO) and water ad libitum, and they were monitored twice daily for health status, no adverse events were observed. Mice were randomly assigned to different groups for all studies. All experiments were designed in accordance to the Arrive guidelines for animal care and protection (Methods S1). ${ }^{16}$

\section{Cell death assay}

Cell death was measured using $1 \mu \mathrm{g} / \mathrm{mL}$ APC Annexin V (BD Pharmingen, San Jose, CA) and $0.5 \mu \mathrm{g} / \mathrm{mL}$ propidium iodide (PI) (MERCK). In brief, $5 \times 10^{4}$ cells/well in 24-well dishes (Life Sciences) were incubated in the presence or absence of different concentrations of IMMUNEPOTENT CRP (ICRP), epirubicin (EPI, Sigma-Aldrich, ST. Louis, MO) or cyclophosphamide (CPA, Sigma-Aldrich) for $24 \mathrm{~h}$ in complete DMEM or RPMI to a final volume of $400 \mu \mathrm{L}$ to obtain the ICRP $\mathrm{CC}_{50}$. For cell death inhibition assays, cells were pretreated $30 \mathrm{~min}$ with or without $5 \mathrm{mM} \mathrm{N}$-acetyl-L-cysteine (NAC), $10 \mu \mathrm{M}$ QVD.oph, $30 \mu \mathrm{M}$ Necrostatin-1 (NEC-1) or $15 \mu \mathrm{M}$ Spautin-1 $(\mathrm{Sp}-1)$, and then co-treated with or without ICRP $\mathrm{CC}_{50}$ for $24 \mathrm{~h}$, as mentioned before. Cells were then detached, washed twice with PBS, suspended in $100 \mu \mathrm{L}$ of binding buffer $(10 \mathrm{mM} \mathrm{HEPES} / \mathrm{NaOH}$, $\mathrm{pH} 7.4,140 \mathrm{mM} \mathrm{NaCl}$ and $2.5 \mathrm{mM} \mathrm{CaCl}_{2}$ ), stained and assessed by BD Accury C6 flow cytometer (Becton Dickinson, Franklin Lakes, NJ). The results were analysed using FlowJo Software (LLC, Ashland, OR).

Loss of mitochondrial membrane potential analysis

For these assays, cells were stained with 500 nM TMRE (SigmaAldrich) to evaluate the loss of mitochondrial membrane potential. In brief, $5 \times 10^{4}$ cells/well in 24-well dishes (Life Sciences) were incubated in the presence or absence of ICRP $\mathrm{CC}_{50}$ for $24 \mathrm{~h}$, as explained above. Cells were then detached, washed with PBS, stained, incubated at $37^{\circ} \mathrm{C}$ for $30 \mathrm{~min}$ and measured by flow cytometry as described above.

\section{ROS generation analysis}

ROS levels were determined by staining cells with $2.5 \mu \mathrm{M} 2^{\prime}, 7^{\prime}$ dichlorofluorescin diacetate (DCFDA) (MERCK). In brief, $5 \times 10^{4}$ cells/well were incubated in the presence or absence of ICRP $\mathrm{CC}_{50}$ for $24 \mathrm{~h}$, as explained above. Cells were then detached, washed with PBS, stained, incubated at $37{ }^{\circ} \mathrm{C}$ for $30 \mathrm{~min}$ and measured using a flow cytometer, as mentioned above.

\section{Autophagosome formation assays}

For flow cytometric assessment, $5 \times 10^{4}$ cells were cultured in 24well plates (Life Sciences) in the presence or absence of ICRP $\mathrm{CC}_{50}$ for $24 \mathrm{~h}$. Cells were then detached, washed with PBS, stained with Autophagy Detection Kit (Abcam, Cambridge, UK) and measured by flow cytometry, as explained above.

For fluorescence microscopy, $5 \times 10^{4}$ cells were cultured in 24well plates (Life Sciences), pre-treated $30 \mathrm{~min}$ with or without 15 $\mu \mathrm{M} \mathrm{Sp}-1$ and then co-treated with or without ICRP $\mathrm{CC}_{50}$ for $24 \mathrm{~h}$, as mentioned above. Cells were then washed twice with PBS and stained with CYTO-ID Autophagy Detection Kit (Enzo Life Science, Farmingdale, NY) following the manufacturer's instructions. Nuclei were counterstained in blue with Hoechst 33342 dye (Enzo Life Science). Images were acquired with an InCellis Imager (BERTIN Instruments, Montigny-le-Bretonneux, France), fluorescence was measured using Image J (NIH Image, Bethesda, MD) to obtain the corrected total cell fluorescence (CTCF) using the following formula: CTCF $=$ integrated density - (area of selected cell * mean fluorescence of background readings).

Western blot analysis

Cells were treated with ICRP $\mathrm{CC}_{50}$ for $24 \mathrm{~h}$ and were lysed in lysis buffer containing $20 \mathrm{mM}$ Tris (pH 6.8), 2\% SDS, $2 \mathrm{mM}$ EDTA and $300 \mathrm{mM} \mathrm{NaCl}$. The protein concentration for each sample was determined using a spectrophotometer in accordance with the manufacturer's recommendations. The proteins were separated by SDS-PAGE and transferred to nitrocellulose membranes. Western blotting was performed with anti-p62 (sc-48402, Santa Cruz Biotechnology, Dallas, TX) and anti- $\beta$-actin (BA3R, abm, Richmond, $B C)$. After incubation with the anti-mouse secondary antibodies conjugated to horseradish peroxidase (ab6728, Abcam), blots were revealed using ECL western blotting substrate (Thermo Scientific, Waltham, MA).

\section{EIF2a assay}

For this assay, $5 \times 10^{5}$ cells were plated in 6-well dishes (Life Sciences) in complete DMEM or RPMI to a final volume of $2 \mathrm{~mL}$, and incubated in the presence or absence of ICRP $\mathrm{CC}_{50}$ for $18 \mathrm{~h}$ or $1 \mu \mathrm{M}$ thapsigargin (thaps) for $2 \mathrm{~h}$. Cells were then collected and fixed with $80 \%$ methanol for $5 \mathrm{~min}$ at $-20^{\circ} \mathrm{C}$, washed with PBS and permeabilized with $0.1 \%$ PBS-Tween for $20 \mathrm{~min}$ at $25^{\circ} \mathrm{C}$. The cells were then washed with PBS, suspended in $50 \mu \mathrm{L}$ of $1 \times \mathrm{PBS} / 10 \%$ $\mathrm{FSB} / 0.3 \mathrm{M}$ glycine, incubated for $30 \mathrm{~min}$ and shaken at $400 \mathrm{rpm}$, $25^{\circ} \mathrm{C}$, followed by the addition of $0.2 \mu \mathrm{L}$ of anti-EIF2S1 (phospho S51) antibody [E90] (ab32157, Abcam) (1:250) for elF2a phosphorylation (P-elF2a) analysis or $0.5 \mu \mathrm{L}$ of anti-EIF2A (3A7A8, Santa Cruz Biotechnology) (1:100) for elF2a total (T-elF2a) assays, cells were incubated for $2 \mathrm{~h}$ and washed with 2\% FACS Buffer (1× PBS and $2 \%$ FBS). Cells were then suspended in $100 \mu \mathrm{L}$ of $1 \times \mathrm{PBS} / 10 \% \mathrm{FSB} / 0.3 \mathrm{M}$ glycine, incubated for $15 \mathrm{~min}$ and shaken at $400 \mathrm{rpm}$ and $25^{\circ} \mathrm{C}$; $0.2 \mu \mathrm{L}$ of goat anti-rabbit IgG H\&L (Alexa Fluor $^{\circledR}$ 488) (ab150077, Abcam) (1:500) or $0.2 \mu \mathrm{L}$ of goat anti-mouse IgG (Alexa Fluor ${ }^{\circledR} 488$ ) $(\mathrm{H}+\mathrm{L}$, Life Technologies) (1:500) were then added for P-elF2a or T-elF2 $\mathrm{a}$ analyses respectively, and incubated for $1 \mathrm{~h}$ in darkness. Cells were washed with $2 \%$ FACS Buffer and the fluorescence was measured by flow cytometry, as mentioned before.

Calreticulin, HSP70, HSP90 and CD47 exposure analyses For this, $5 \times 10^{4}$ cells were seeded in 24-well plates and treated with ICRP $\mathrm{CC}_{50}, \mathrm{EPI} \mathrm{CC}_{50}$ or $\mathrm{CPA} \mathrm{CC}_{50}$ for $24 \mathrm{~h}$. Cells were detached, washed and incubated for $1 \mathrm{~h}$ at $25^{\circ} \mathrm{C}$ with $2 \mu \mathrm{g} / \mathrm{mL}$ Calreticulinantibody (FMC-75, Enzo Life Science), $0.8 \mu \mathrm{g} / \mathrm{mL}$ HSP70-antibody (F-3, Santa Cruz Biotechnology), $0.8 \mu \mathrm{g} / \mathrm{mL}$ HSP90-antibody (F-8, Santa Cruz Biotechnology), $3 \mu \mathrm{g} / \mathrm{mL}$ CD47 human-antibody (B6H12, Santa Cruz Biotechnology) or $3 \mu \mathrm{g} / \mathrm{mL}$ CD47 mouseantibody (MIAP301, Santa Cruz Biotechnology), in 2\% FACS buffer, cells were washed and incubated for $30 \mathrm{~min}$ in darkness at $25^{\circ} \mathrm{C}$ with goat anti-mouse IgG (Alexa Fluor 488) $(\mathrm{H}+\mathrm{L}$, Life Technologies) (1:1500) or anti-rat IgG (Alexa Fluor 488) $(H+\mathrm{L}$, Life Technologies) (1:1500) in 2\% FACS buffer, cells were then washed, suspended in $2 \%$ FACS buffer with 7-AAD (Life Technologies) 
(1:1000) or Fixable viability stain 780 (BD Biosciences) (1:1000) and incubated protected from light for $10 \mathrm{~min}$ at $25^{\circ} \mathrm{C}$. The surface exposure of CRT, HSP70, HSP90 and CD47 was determined by flow cytometry among viable (7-AAD-negative or Fixable viability stain 780-negative) cells.

\section{ATP release assay}

Supernatants of ICRP, EPI or CPA CC $5_{50}$-treated cells $\left(2 \times 10^{5}\right)$ were used to assess extracellular ATP by a luciferase assay (ENLITEN kit, Promega, Madison, WI), following the manufacturer's instructions. Bioluminescence was determined in a Synergy HT microplate reader, using the Software Gen5 (BioTek, Winooski, VT) at $560 \mathrm{~nm}$.

High-mobility group box 1 release assay

For this assay, $2 \times 10^{5}$ cells were treated with ICRP or EPI CC ${ }_{50}$ for $24 \mathrm{~h}$ or $48 \mathrm{~h}$. Supernatants were used to assess extracellular HMGB1 using the HMGB1 BioAssay ELISA Kit (Human) for MCF-7 and MDA-MB-231 cells (US Biological Life Science, Salem, MA), and the HMGB1 BioAssay ELISA Kit (Mouse) for 4T1 cells (US Biological Life Science), following the manufacturer's instructions, in a spectrophotometer at a wavelength of $450 \mathrm{~nm}$.

\section{Generation of mouse BMDCs}

To obtain bone marrow-derived dendritic cells (BMDCs), seven-toeight-week-old BALB/c mice were anaesthetised with an intraperitoneal injection of ketamine $(80 \mathrm{mg} / \mathrm{kg}$ body weight) and xylazine $(10 \mathrm{mg} / \mathrm{kg}$ body weight) and were euthanised by cervical dislocation ( $n=5$ mice). Bone marrow was removed from femur and tibia after mouse death by flushing into complete RPMI (Life Technologies), as previously described. ${ }^{17}$ Eluted cells were cultured at $37^{\circ} \mathrm{C}$ in a controlled humidified atmosphere with 5\% $\mathrm{CO}_{2}$ for 5 days in complete RPMI and $20 \mathrm{ng} / \mathrm{mL} \mathrm{IL-4}$ and GM-CSF (R\&D Systems, Minneapolis, MN), until approximately $50 \%$ of cells were CD11c+.

T-cell isolation

Seven-to-eight-week-old BALB/C mice were anaesthetised as mentioned above. Blood was obtained by cardiac puncture, and then cervical dislocation was performed. Peripheral blood mononuclear cell (PBMC) isolation was performed by density-gradient centrifugation, using Ficoll-Hypaque-1119 (MERCK). CD3+ cells were isolated from total PBMCs by positive selection using magnetic-activated cell sorting microbead technology with antiCD3+-biotin and anti-biotin microbeads (Miltenyi Biotec, Bergisch Gladbach, Germany), following the manufacturer's instructions. Primary murine $\mathrm{CD} 3+$ cells were maintained in complete RPMI and incubated at $37^{\circ} \mathrm{C}$ in a controlled humidified atmosphere with $5 \% \mathrm{CO}_{2}$.

\section{Killed cancer cell (KCC) obtention}

For the obtention of 4T1 killed cancer cells (KCC), we treated $4 \mathrm{~T} 1$ cells with $\mathrm{CC}_{100}$ of ICRP $\left(0.5 \mathrm{U} / \mathrm{mL}\right.$, ICRP-KCC), $\mathrm{CC}_{100}$ of EPI (10 $\mu \mathrm{M}, \mathrm{EPI}-\mathrm{KCC}$ ) or $\mathrm{CC}_{100}$ of CPA (35 mM, CPA-KCC), and the dead cells obtained were then washed and detached; cell death (>90\%) was confirmed using trypan blue staining and flow cytometry.

\section{ICRP-KCC-mediated BMDC maturation}

BMDCs were suspended in complete RPMI at a concentration of $1 \times 10^{6}$ cells $/ \mathrm{mL}$ and stimulated with ICRP-killed cancer cells (ICRPKCC) $\left(3 \times 10^{6}\right.$ cells $/ \mathrm{mL}$ at a ratio of $1: 3$ BMDCs to ICRP-treated $4 \mathrm{~T} 1$ cells (BMDC-ICRP-KCC)). Control BMDCs were left untreated or stimulated with $1 \mu \mathrm{g} / \mathrm{mL}$ lipopolysaccharide (LPS) (MERCK). After $24 \mathrm{~h}$, culture supernatants were removed and stored at $-80^{\circ} \mathrm{C}$ to analyse TNF-a release by flow cytometry (BD CBA Mouse Th1/Th2 Cytokine Kit, BD Biosciences, San Jose, CA), and wells were washed twice with PBS before the next co-culture (with the addition of $T$ lymphocytes). Additionally, some BMDC-Control and BMDC-ICRPKCC wells were collected to analyse DC marker expression.
DC marker expression

For this assay, $1 \times 10^{5}$ BMDCs were suspended in $100 \mu \mathrm{L}$ of $2 \%$ FACS buffer, and maturation was analysed by immunostaining using anti-CD11c-Alexa Fluor 488 (R\&D Systems), anti-CD80-FITC and anti-CD86-APC (BD Biosciences) at $25^{\circ} \mathrm{C}$ for $30 \mathrm{~min}$, and washed twice with PBS. Cell surface markers were evaluated by flow cytometry, as mentioned above.

BMDC T-lymphocyte co-culture

BMDC-Control or BMDC-ICRP-KCC were maintained in complete RPMI at a concentration of $1 \times 10^{6}$ cells $/ \mathrm{mL}$. Allogeneic BALB/c $\mathrm{mCD} 3+$ cells were then added to each well at $3 \times 10^{6}$ cells $/ \mathrm{mL}$ (at a ratio of 1:3 DCs to CD3 + cells), and incubated for $96 \mathrm{~h}$ at $5 \% \mathrm{CO}_{2}$ and $37{ }^{\circ} \mathrm{C}$. Supernatants were then removed, stored at $-80^{\circ} \mathrm{C}$ to further analyse TNF-a, IFN- $\gamma$, IL-4 and IL- 5 levels by flow cytometry (BD CBA Mouse Th1/Th2 Cytokine Kit, BD Biosciences), and lymphocytes were washed with PBS, and suspended in complete RPMI to be used in the next co-culture (T lymphocytes with cancer cells).

T lymphocyte-4T1 cell co-culture

Viable $4 \mathrm{~T} 1$ cells were seeded at a concentration of $1 \times 10^{5}$ cells/ $\mathrm{mL}$. Cells were then stained with $0.1 \mu \mathrm{L} / \mathrm{mL}$ of calcein-AM (BD Biosciences) for $30 \mathrm{~min}$ and washed twice with PBS. Next, unprimed (previously co-cultured with BMDC-Control) or primed (previously co-cultured with BMDC-ICRP-KCC) allogeneic BALB/C CD3 + cells were added to each well at $5 \times 10^{5}$ cells $/ \mathrm{mL}$ (at a ratio of 1:5 cancer cells to CD3+ cells); 4T1-T-lymphocyte co-culture was incubated at $37{ }^{\circ} \mathrm{C}$ and $5 \% \mathrm{CO}_{2}$ for $24 \mathrm{~h}$. Supernatants were removed and stored at $-80^{\circ} \mathrm{C}$ to further analyse IFN- $\gamma$, IL-4 and IL5 levels, as mentioned above. Cancer cells were then washed and detached to analyse 4T1-calcein-negative cells by flow cytometry, as described above.

Prophylactic vaccination

For this, 4T1 cells were treated with $0.5 \mathrm{U} / \mathrm{mL}$ ICRP, $10 \mu \mathrm{M}$ EPI or $35 \mathrm{mM}$ CPA for $24 \mathrm{~h}$; cells were then washed, detached and cell death was confirmed using trypan blue staining and flow cytometry, as previously indicated to obtain the KCC. Seven-toeight-week-old BALB/c mice were inoculated subcutaneously (s.c.) with $1.5 \times 10^{6}$ ICRP-killed 4T1 cells (ICRP-KCC, $n=10$ mice), $1.5 \times$ $10^{6}$ EPI-killed 4T1 cells (EPI-KCC, $n=10$ mice), $1.5 \times 10^{6}$ CPA-killed 4T1 cells (CPA-KCC, $n=10$ mice) or with PBS ( $n=10$ mice) on the left flank side. On day 7 after vaccination, the mice were challenged s.c. on the opposite flank with $5 \times 10^{5}$ viable $4 \mathrm{~T} 1$ cells.

\section{Tumour volume measurements}

Tumour volume was measured three times a week, using a calliper (Digimatic Calliper Mitutoyo Corporation, Japan), this was determined with the following formula: tumour volume $\left(\mathrm{mm}^{3}\right)$ $=4+/ 3 * \mathrm{~A}$ (length) $* \mathrm{~B}$ (width) $* \mathrm{C}$ (height). When the tumour reached the parameters that confine mouse pain and distress, or mice presented two or more parameters of pain and distress, as postulated by the Institutional Animal Research and Welfare Ethics Committee (CEIBA), mice were anaesthetised as described above and were euthanised by cervical dislocation.

\section{Long-term memory assays}

Mice in complete remission after ICRP-KCC prophylactic vaccination were rechallenged with $5 \times 10^{5}$ viable $4 \mathrm{~T} 1$ cells in $100 \mu \mathrm{L}$ of PBS into the opposite flank ( $n=9$ mice), and naive mice were used as control ( $n=9$ mice). Tumour volume and mice survival were evaluated, as described above.

Additionally, 3 days after tumour rechallenge, tissues from tumour-draining lymph nodes (TDLN) and tumour re-challenge sites were obtained from naive and ICRP-KCC mice, and fixed in $3.7 \%$ neutral formalin, embedded in paraffin, sectioned $(5-\mu \mathrm{m}$ thickness) and stained with H\&E (MERCK). Histopathological 
analyses were done by an external veterinarian pathologist (National professional certificate 2593012). Blood was obtained by cardiac puncture from anaesthetised mice as described above, and PBMC isolation was performed by density-gradient centrifugation, using Ficoll-Hypaque-1119 (MERCK). Cells from tumour rechallenge site, TDLN and spleen were isolated using $70-\mu \mathrm{m}$ cell strainers (MERCK) and suspended in 2\% FACS buffer. PBMCs, TDLN cells and tumour rechallenge site cells were stained with Mouse $T$ lymphocyte antibody cocktail: PE-Cy7 CD3e, PE CD4 and FITC CD8 (BD Pharmingen) following the manufacturer's instructions. Maturation of DCs was analysed by immunostaining of cells from lymph nodes using anti-CD11c-Alexafluor 488 (R\&D Systems), and anti-CD86-APC (BD Biosciences) at $25^{\circ} \mathrm{C}$ for $30 \mathrm{~min}$ and washed twice with PBS. Cell surface markers were evaluated by flow cytometry, as mentioned above. Viable $4 \mathrm{~T} 1$ cells were seeded at a concentration of $1 \times 10^{5}$ cells $/ \mathrm{mL}$, stained with $0.1 \mu \mathrm{L} / \mathrm{mL}$ of calcein-AM (BD Biosciences) for $30 \mathrm{~min}$ and washed twice with PBS. Next, splenocytes from naive or ICRP-KCC mice were added to each well at $40 \times 10^{5}$ cells $/ \mathrm{mL}$ (at a ratio of 1:40 cancer cells to splenocytes); $4 \mathrm{~T} 1$-splenocyte co-culture was incubated at $37^{\circ} \mathrm{C}$ and $5 \% \mathrm{CO}_{2}$ for $24 \mathrm{~h}$. Supernatants were removed and stored at $-80^{\circ} \mathrm{C}$ to further analyse IFN- $\gamma$, TNF- $\alpha, \mathrm{IL}-2, \mathrm{IL}-4$ and IL- 5 levels, as mentioned above. Cancer cells were then washed and detached to analyse 4T1-calcein-negative cells by flow cytometry, as described above ( $n=6$ mice per group).

Statistical analysis

Data were analysed using GraphPad Prism Software (GraphPad Software Inc., San Diego, (A) and shown as mean \pm SD of triplicates from three independent experiments. For in vitro studies, statistical analyses were done using paired Student's $t$ test, and for in vivo and ex vivo studies, Mann-Whitney tests and two-tailed unpaired Student's $t$-tests were performed.

\section{RESULTS}

IMMUNEPOTENT CRP induces loss of mitochondrial membrane potential, pro-survival autophagosome formation and ROSdependent cell death in MCF-7, MDA-MB-231 and 4T1 cells ICRP induced cell death in all cell lines, in a concentrationdependent manner, as shown in Fig. 1a. Cell death in $30 \%$ of the cells $\left(\mathrm{CC}_{30}\right)$ was reached at $1 \mathrm{U} / \mathrm{mL}$ in MCF-7 and MDA-MB-231, and $0.1 \mathrm{U} / \mathrm{mL}$ in $4 T 1$ cells. $C C_{50}$ by ICRP was caused at $1.25 \mathrm{U} / \mathrm{mL}$ in MCF-7 and MDA-MB-231 cells, and $0.15 \mathrm{U} / \mathrm{mL}$ in $4 \mathrm{~T} 1$ cells, whereas $\mathrm{CC}_{80}$ was induced at $1.5 \mathrm{U} / \mathrm{mL}$ in human breast cancer cells, and $0.2 \mathrm{U} / \mathrm{mL}$ in $4 \mathrm{~T} 1$ cells, $\mathrm{CC}_{100}$ was reached at $2 \mathrm{U} / \mathrm{mL}$ in MCF-7 and MDA-MB-231, and $0.5 \mathrm{U} / \mathrm{mL}$ in $4 \mathrm{~T} 1$ cells, where we observed more than $90 \%$ of cell death (Fig. 1a). The ICRP-killed 4T1 cells (ICRP$\mathrm{KCC})$ were generated with this $\mathrm{CC}_{100}$. Loss of mitochondrial membrane potential was induced in $55-65 \%$ of MCF-7, MDA-MB231 and $4 \mathrm{~T} 1$ cells treated with ICRP $\mathrm{CC}_{50}$ for $24 \mathrm{~h}$ (Fig. $1 \mathrm{~b}$ ), also, this treatment generated an increase of ROS levels in $45-55 \%$ of MCF7, MDA-MB-231 and 4T1 cells (Fig. 1c). Moreover, we observed autophagosome formation in $40-55 \%$ of MCF-7, MDA-MB-231 and 4T1 cells assessed by flow cytometry (Fig. 1d). This autophagosome formation was confirmed by fluorescence microscopy (Fig. 1e), which was inhibited in the presence of the autophagy inhibitor Sp-1 (Supplementary Fig. 1A). In addition, p62 downregulation was induced in MCF-7, MDA-MB-231 and 4T1 cells treated with ICRP $\mathrm{CC}_{50}$ for $24 \mathrm{~h}$ (Supplementary Fig. 1B).

The ROS scavenger NAC significantly inhibited ICRP-induced cell death, whereas the autophagy inhibitor Sp-1 significantly potentiated ICRP-mediated cell death (Fig. 1f). No significant changes were observed with the necroptosis inhibitor NEC-1 in MCF-7, MDA-MB-231 and 4T1 cells (Fig. 1f). Additionally, the caspase inhibitor QVD significantly potentiated ICRP-mediated cell death in MDA-MB-231 and 4T1 cells, whereas no significant changes were observed in MCF-7 cells (Fig. 1f).
IMMUNEPOTENT CRP causes elF2a phosphorylation and DAMP emission in MCF-7, MDA-MB-231 and 4T1 cells

ICRP induced P-elF2a in $40-60 \%$ of all cell lines treated with ICRP $\mathrm{CC}_{50}$ for $18 \mathrm{~h}$; similar results were found when cells were treated with $1 \mu \mathrm{M}$ Thaps for $2 \mathrm{~h}$ (Fig. 2a); importantly, no changes in total elF2a expression (T-elF2a) were found after treatments (Supplementary Fig. 2).

In addition, ICRP $\mathrm{CC}_{50}$ treatment for $24 \mathrm{~h}$ induced $3.73 \pm 0.83-$, $3.07 \pm 0.97-$ and $3.20 \pm 0.59$-fold CRT exposure (Fig. 2b), $2.61 \pm 0.82-$, $1.63 \pm 0.24$ - and $6.51 \pm 1.74$-fold HSP70 exposure (Fig. 2c), $2.55 \pm$ $0.26-, 1.93 \pm 0.31-$ and $6.23 \pm 1.35$-fold HSP90 exposure (Fig. $2 \mathrm{~d}$ ) and $135 \pm 31.38-, 140.99 \pm 50.38$ - and 7.30 \pm 3.92-fold ATP release (Fig. 2e) in MCF-7, MDA-MB-231 and 4T1 cells, respectively, when compared with untreated cells. ICRP-treated cells also presented a decrease in CD47 exposure of $0.66 \pm 0.21-, 0.79 \pm 0.07$ - and $0.49 \pm 0.17$-fold in MCF-7, MDA-MB-231 and 4T1 cells, respectively, as compared with untreated control (Supplementary Fig. 3). Additionally, EPI $\mathrm{CC}_{50}$ treatment for $24 \mathrm{~h}$ induced $6.61 \pm 1.61-, 2.69 \pm 0.33-$ and $1.46 \pm 0.20$ fold CRT exposure (Fig. 2b), $3.41 \pm 0.64-, 2.56 \pm 0.45-$ and $1.66 \pm 0.19-$ fold HSP70 exposure (Fig. 2c), $6.24 \pm 0.28-, 2.98 \pm 0.69-$ and $2.29 \pm$ 0.95 -fold HSP90 exposure (Fig. 2d) and $2.02 \pm 0.92-, 12.61 \pm 1.47-$ and $3.07 \pm 0.66$-fold ATP release (Fig. 2e) in MCF-7, MDA-MB-231 and $4 \mathrm{~T} 1$ cells, respectively, in contrast with untreated cells.

Our results also revealed that ICRP $\mathrm{CC}_{50}$ treatment for $24 \mathrm{~h}$ induced $1.58 \pm 0.07-, 1.65 \pm 0.25-$ and $1.34 \pm 0.28$-fold HMGB1 release, and the same treatment for $48 \mathrm{~h}$ triggered $5.32 \pm 0.83-$, $4.94 \pm 1.14$ - and $1.49 \pm 0.04$-fold HMGB1 release in MCF-7, MDAMB-231 and 4T1 cells, respectively, as compared with untreated cells. Finally, EPI CC $C_{50}$ treatment for $24 \mathrm{~h}$ caused $7.51 \pm 1.12-, 2.66$ \pm 0.61 - and $1.13 \pm 0.11$-fold HMGB1 release, and this treatment for $48 \mathrm{~h}$ provoked $7.55 \pm 0.89-, 2.87 \pm 0.61-$ and $1.29 \pm 0.08$-fold HMGB1 release in MCF-7, MDA-MB-231 and 4T1 cells, respectively, in contrast with untreated cells (Fig. 2f).

Interestingly, CPA $\mathrm{CC}_{50}$ treatment for $24 \mathrm{~h}$ only induced significative DAMP emission in MCF-7 cells, but not MDA-MB231 and 4T1 cells (Supplementary. Fig. 4)

Dead tumour cells obtained after ICRP treatment induce maturation of BMDCs

After determining that the principal biochemical characteristics of immunogenic cell death were evoked after ICRP treatment, we evaluated the capacity of the dead cells (obtained after ICRP $\left(C_{100}\right)$ treatment, ICRP-KCC) to mature BMDCs. As observed in Fig. $3 a$, b, the exposure of BMDCs to ICRP-KCC (BMDC-ICRP-KCC) significantly increased the expression of CD80 (57\%), and CD86 (65\%), whereas it maintained CD11c expression (48\%), in comparison with unstimulated BMDCs (C80: 44\%, CD86: $45 \%$ and CD11c: 49\%). These results resemble the ones observed by our positive control, LPS, which significantly incremented CD80 (56\%) and CD86 expression (70\%), and also maintained CD11C expression (48\%) in these cells. Furthermore, a significant increase in TNF-a release was observed in BMDCs stimulated with ICRP-KCC $(760.68 \pm 209.84 \mathrm{pg} / \mathrm{mL})$ or LPS $(7763.41 \pm 1158.50 \mathrm{pg} / \mathrm{mL})$, in comparison with unstimulated BMDCs $(52.72 \pm 1.66 \mathrm{pg} / \mathrm{mL})$ (Fig. 3c). Thus, ICRP-KCC induced BMDC maturation.

\section{Mature BMDCs exposed to ICRP-tumour cell lysate trigger} anticancer immune responses

After the evaluation of ICRP-KCC-mediated BMDC maturation, the next step was to investigate if these mature cells could induce Tcell priming. Figure $3 \mathrm{~d}$, e shows a significant increase of TNF-a $(380 \pm 139.48 \mathrm{pg} / \mathrm{mL})$ and IFN- $\gamma(650.37 \pm 12.86 \mathrm{pg} / \mathrm{mL})$ release in the co-culture of BMDC-ICRP-KCC and T-cells, in contrast to the coculture of BMDC-Control and T cells (TNF-a: $95.89 \pm 71.63 \mathrm{pg} / \mathrm{mL}$ and IFN- $\mathrm{Y}$ : $185.67 \pm 75.09 \mathrm{pg} / \mathrm{mL}$ ). No significant differences were detected in TH-2 cytokines, IL-4 and IL-5 release (Supplementary. Table 1). Primed T cells obtained after co-culture with BMDC-ICRPKCC caused a cytotoxic effect in up to $70 \%$ of $4 \mathrm{~T} 1$ cells, whereas 
a

MCF-7
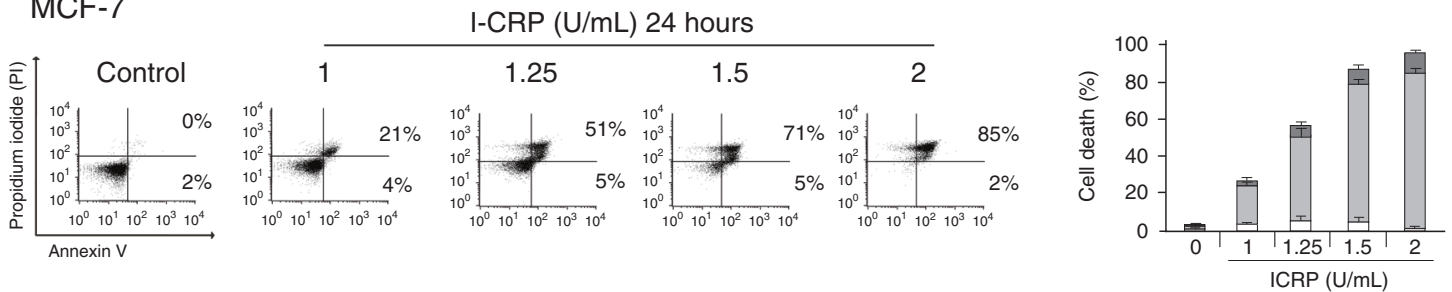

$\square$ AnnexinV-,PI+ $\square$ Annexin $\mathrm{A}_{+}, \mathrm{PI}_{+}$ Annexin $\mathrm{V}+\mathrm{PI}-$

MDA-MB-231

I-CRP (U/mL) 24 hours

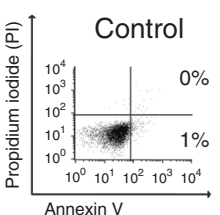

4T1

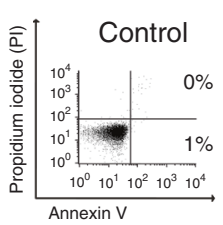

b

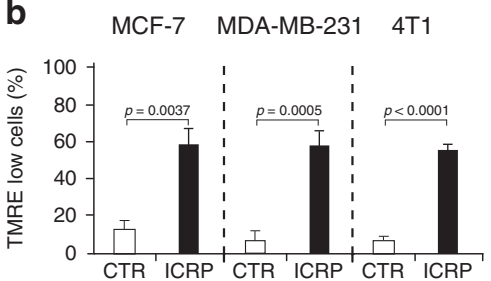

e

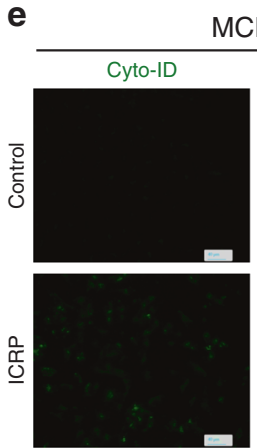

f

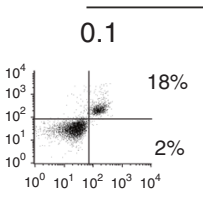

MCF-7
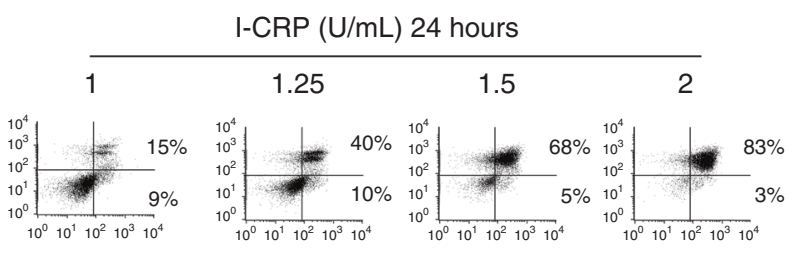

I-CRP (U/mL) 24 hours

0.15

0.2
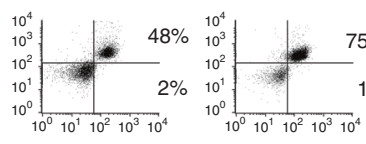

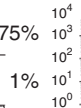

(10)

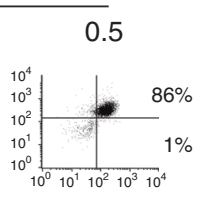

C

MCF-7 MDA-MB-231 $4 \mathrm{~T} 1$

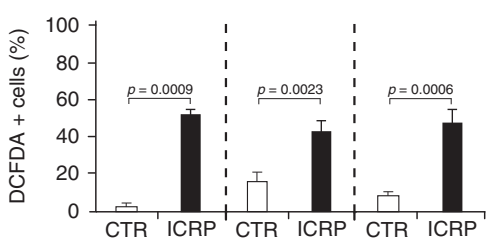

MDA-MB-231
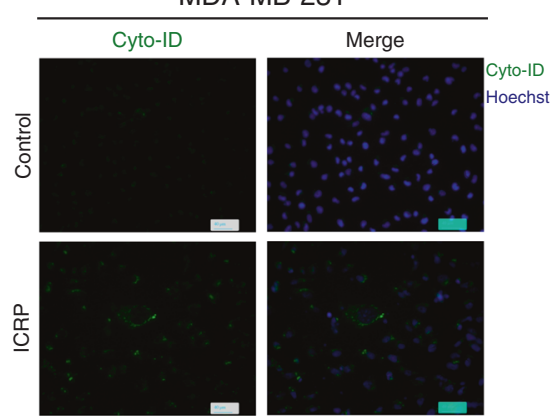

MDA-MB-231
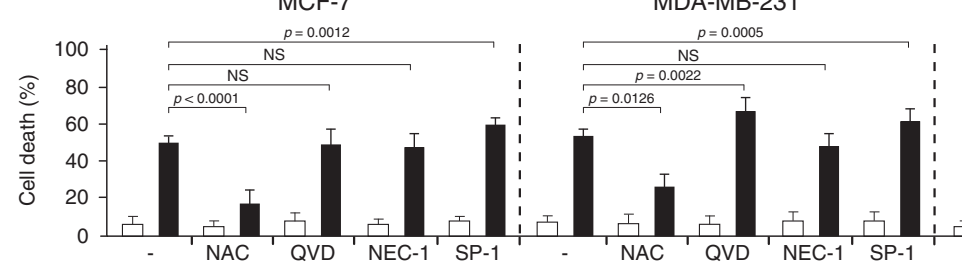
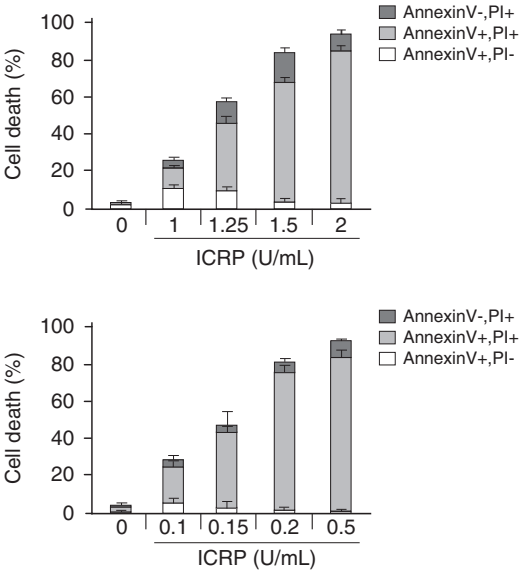

d
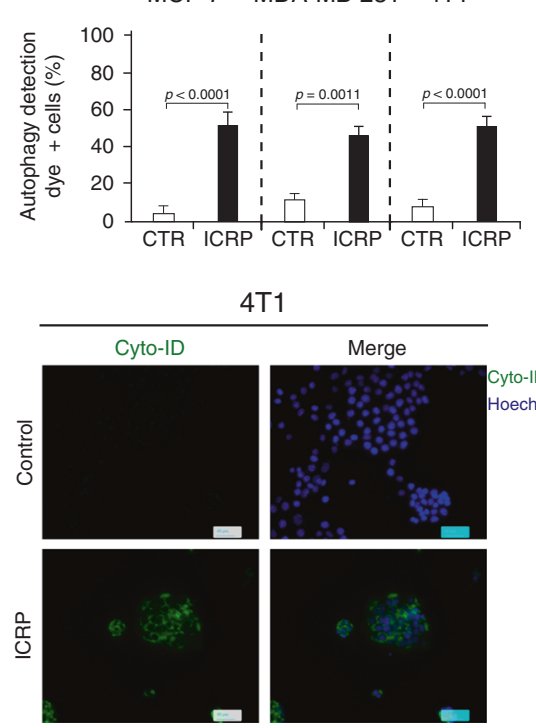

$4 \mathrm{~T}$
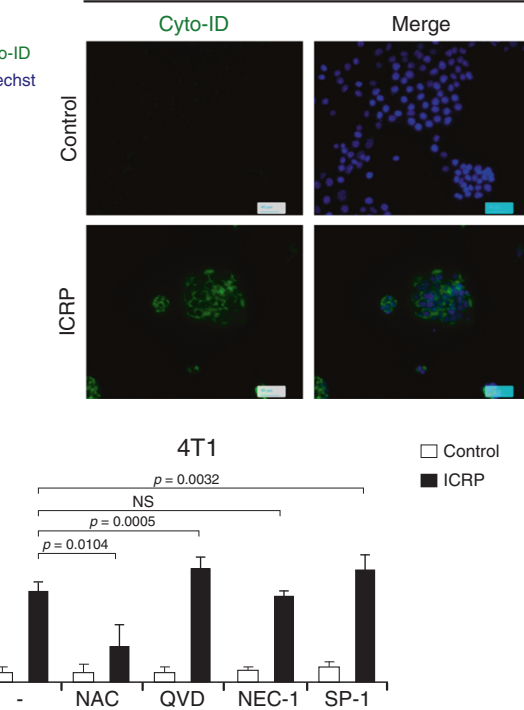

the cytotoxicity induced by unprimed T cells was up to $19 \%$ of cancer cells; no cytotoxicity was detected in 4T1 cells without T cells (Fig. $3 \mathrm{f}$ and Supplementary. Fig. 5). In addition, a significant increase in IFN- $\gamma$ release was observed in the co-culture of primed T cells with $4 \mathrm{~T} 1$ cancer cells $(192.29 \pm 96.54 \mathrm{pg} / \mathrm{mL})$, in comparison with the co-culture of unprimed T cells with $4 \mathrm{~T} 1$ cells $(8.44 \pm 4.55$ $\mathrm{pg} / \mathrm{mL}$ ) (Fig. $3 \mathrm{~g}$ ). No significant differences were detected in $\mathrm{TH}-2$ cytokines, IL-4 and IL-5 release (Supplementary Table 1). These data confirm the efficient antigen presentation by BMDC-ICRP-KCC to $T$ cells and the immunocompetence of these $T$ cells against $4 \mathrm{~T} 1$ cells.

Prophylactic vaccination with ICRP-KCC prevents tumour establishment in BALB/c mice

In order to test the ability of ICRP-KCC to activate adaptive immune system in vivo, we performed a well-established 
Fig. 1 IMMUNEPOTENT CRP induces loss of mitochondrial membrane potential, pro-survival autophagosome formation and ROSdependent cell death in MCF-7, MDA-MB-231 and 4T1 cells. a Representative dot plots (left) and quantifications (right) of cell death measured by flow cytometry through Annexin-V and PI staining in MCF-7, MDA-MB-231 and 4T1 cells treated with different concentrations of ICRP for $24 \mathrm{~h}$. b-d Quantifications of loss of mitochondrial membrane potential evaluated through TMRE staining (b) ROS levels assessed through DCFDA staining (c) or autophagosome formation measured through Green Detection Reagent staining (d) by flow cytometry in the absence (control, shown in white bar) or presence (shown in black bar) of ICRP CC 50 for $24 \mathrm{~h}$ in MCF-7, MDA-MB-231 and 4T1 cells. e Representative immunofluorescence images of CYTO-ID staining in MCF-7, MDA-MB-231 and 4T1 cells left untreated (control) or treated with ICRP CC ${ }_{50}$ for $24 \mathrm{~h}$. Nuclei were counterstained in blue with Hoechst 33342 dye. f Quantification of cell death (Annexin V-, PI+, Annexin V + , PI + , Annexin $\mathrm{V}+$ and $\mathrm{PI}-$ ) measured by flow cytometry through Annexin-V and PI staining in MCF-7, MDA-MB-231 and 4T1 cells in the absence (control, shown in white bar) or presence (shown in black bar) of ICRP $\mathrm{CC}_{50}$ for $24 \mathrm{~h}$ without co-treatment (-) or co-treated with $\mathrm{N}$-acetyl cystein (NAC), QVD-OPH (QVD), Necrostatin-1 (NEC-1) or Spautin-1 (SP-1). The means $( \pm S D)$ of triplicates of at least three independent experiments were graphed.

prophylactic tumour vaccination model in immunocompetent BALB/c mice ${ }^{4,18}$ (Fig. 4). All unvaccinated (PBS) mice reached a correct tumour establishment on the challenge site (Fig. 4a), while immunisation of mice with ICRP-KCC prevented tumour growth at the challenge site in nine out of ten mice (Fig. 4b). Additionally, vaccinated mice with $\mathrm{EPI}-\mathrm{KCC}$ induced tumour regression in $7 / 10$ mice (Fig. 4c), while vaccination with CPA-KCC induced tumour regression at the challenge site in only $2 / 10$ mice (Fig. $4 d$ ). These data confirmed that ICRP-KCC induced a potent immune response in vivo, reflected in $90 \%(9 / 10)$ of 60 -day survival rates of mice in the ICRP-KCC group, whereas EPI induced 70\% (7/10) 60-day survival, CPA induced 20\% (2/10) survival and all PBS mice were euthanised by day 20 (10/10) (Fig. 4e).

Prophylactic vaccination with ICRP-KCC induces long-term antitumour memory in BALB/C mice

To investigate the effect of ICRP-KCC on the memory response in vivo, tumour-free mice that survived 150 days from a previous prophylactic vaccination with ICRP-KCC were rechallenged with viable 4T1 cancer cells, naive mice challenged with viable 4T1 cancer cells were used as control (Fig. 5a). The results show that tumour growth was prevented in rechallenged mice, while continuous tumour growth was observed in naive mice, challenged for the first time (Fig. 5b). This reflected in 100\% (9/9) of survival in ICRP-KCC rechallenged mice, while naive mice perished by day 15 (9/9) (Fig. 5c). These results strongly suggest the stimulation of long-term antitumour immune memory by ICRPKCC prophylactic vaccination.

To better characterise this immune response, we assessed tumour establishment, DC maturation, T-cell distribution and splenocyte-tumour-specific cytotoxicity after three days of tumour challenge (naive mice)/rechallenge (ICRP-KCC) (Supplementary Fig. 6). Histopathological analyses of tumour-draining lymph nodes showed a diffuse lymphoid hyperplasia in naive mice, whereas ICRP-KCC mice present a follicular lymphoid hyperplasia, indicating a modulated response associated with immunological memory (Fig. $5 \mathrm{~d}$ ). Due to these differences, we next evaluated the proportion of mature dendritic cells in tumourdraining lymph nodes. The results indicated that rechallenged ICRP-KCC group did not show significant difference in the percentage of $D C s$, but a higher proportion of mature DCs $(C D 11 c+C D 86+)$ were present when compared with challenged naive mice (Fig. $5 \mathrm{e}$ ); on the other hand, studies of T-cell proportion in TDLNs revealed no differences in total CD3+ cells, a significant decrease of CD4+ T cells and an increase of CD8+ T cells in ICRPKCC mice, when compared with naive mice (Fig. $5 f$ ).

Then, we assessed the proportion of T cells in peripheral blood, and no differences were detected in total CD3+ cells, while a significant decrease of CD4+ T cells and an increase of CD8+ $\mathrm{T}$ cells was observed in ICRP-KCC mice in contrast with naive mice (Fig. 5g).

Moreover, histopathological analyses of the tumour rechallenge site reveal that naive mice presented tumour establishment with an extensive infiltration of neoplastic cells in the striated muscle tissue and these cells demonstrated an intense mitotic activity (Fig. 5h left). On the other hand, ICRP-KCC mice showed a discrete infiltration of neoplastic cells in the striated muscle tissue, observing a strong infiltration of lymphocytes and polymorphonuclear cells (Fig. 5h right). Additionally, we observed an increase in total CD3+ cells, a significant decrease in CD4+ $T$ cells and a significant increase in CD8 $+T$ cells in the tumourrechallenged site of ICRP-KCC mice, when compared with naive mice (Fig. 5i). Furthermore, splenocytes from ICRP-KCC mice mediated a cytotoxic effect in 4T1 cells, inducing loss of cell viability in up to $50 \%$ of cancer cells, whereas no significant cytotoxic effect was detected in 4T1 cells co-cultured with splenocytes from naive mice (Fig. 5j and Supplementary. Fig. 7), indicating a tumour-specific cytotoxicity. Finally, a significant increase in IFN- $\gamma(95.05 \pm 40.01 \mathrm{pg} / \mathrm{mL})$, TNF-a $(4239.85 \pm 784.34$ $\mathrm{pg} / \mathrm{mL})$ and IL-2 (20.97 $\pm 0.68 \mathrm{pg} / \mathrm{mL})$ release was observed in the co-culture of $4 \mathrm{~T} 1$ cells with splenocytes from ICRP-KCC mice, in comparison with the co-culture of 4T1 cells with splenocytes from naive mice (IFN- $\mathrm{:} 27.66 \pm 15.12 \mathrm{pg} / \mathrm{mL}$, TNF-a: $3310.46 \pm 422.46$ $\mathrm{pg} / \mathrm{mL}$ and IL-2: $10.69 \pm 2.94 \mathrm{pg} / \mathrm{mL}$ ) (Fig. $5 \mathrm{k}$ ), and no significant differences were detected in TH-2 cytokines, IL-4 and IL-5 release (Supplementary Table 2).

\section{DISCUSSION}

IMMUNEPOTENT CRP is a promising immunotherapy that induces regulated cell death in cancer cells. In T-acute lymphoblastic leukaemia (T-ALLL) cells (Molt-4 and CEM), ICRP provokes ROSdependent apoptosis accompanied by mitochondrial and nuclear alterations. ${ }^{11}$ On the other hand, in cell lines from cervical (HeLa and SiHa cells) and lung cancer (A529 cells), ICRP induces nonapoptotic cell death (caspase-independent) that relies on ROS production, involving cell cycle arrest and loss of mitochondrial membrane potential. ${ }^{9,10,13}$ In this work, we demonstrated that ICRP caused caspase- and necrosome-independent regulated cell death that relies on ROS production in MCF-7, MDA-MB-231 and $4 \mathrm{~T} 1$ cells, suggesting a conserved mechanism of action in solid tumours, and with some shared characteristics in all the cell lines tested to this day. Other treatments also induce different cell death mechanisms, being specific for the type of cancer cell line tested with shared characteristics in the cytotoxic pathway. ${ }^{19,20}$ In addition, no differences in cell death were observed in NEC-1 cotreated cells, which indicates that ICRP-mediated regulated cell death is different from necroptosis.

Moreover, inhibition of autophagy significantly potentiated ICRP-induced cell death, suggesting that ICRP induces pro-survival autophagosome formation in MDA-MB-231 and 4T1 cells, corresponding with our previous reports in MCF-7. ${ }^{13}$ The induction of autophagy as a protective mechanism in cancer cells has also been demonstrated with other cancer treatments, including chemotherapy and radiation. ${ }^{21}$ Furthermore, inhibition of caspases also resulted in a significant augmentation of ICRP-mediated cell death in MDA-MB-231 cells and 4T1 cells, but not MCF-7 cells. These results could be related with the "Phoenix Rising" pathway of cell death-induced tumour repopulation, in which caspase 3 plays key roles that have been demonstrated in 4T1 and MDA-MB- 
a

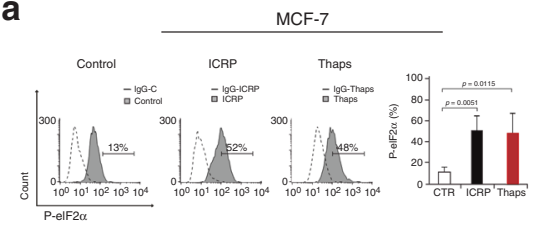

b

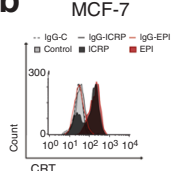

MCF-7

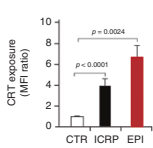

e

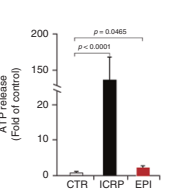

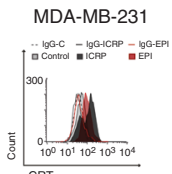

MDA-MB-231

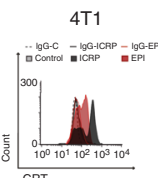

$4 \mathrm{~T} 1$

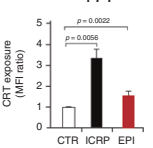

MDA-MB-231
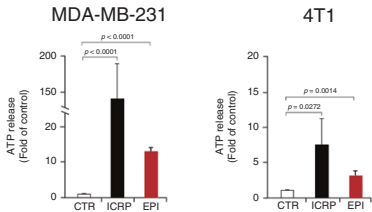

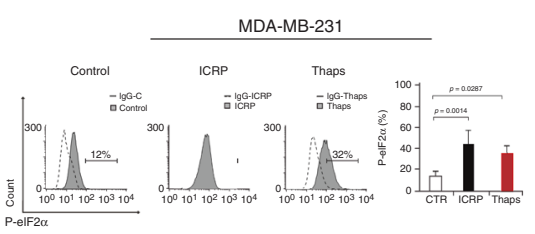

C

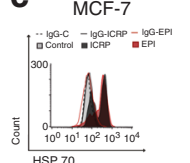

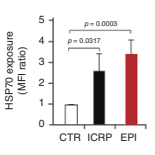

f

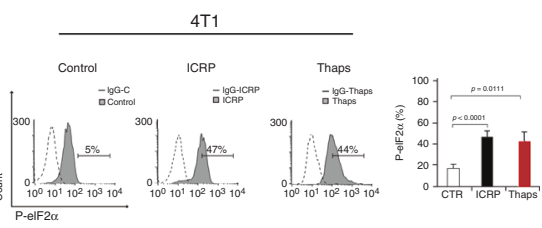

d MCF-7

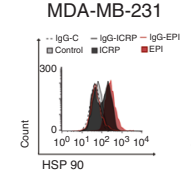

MCF-7

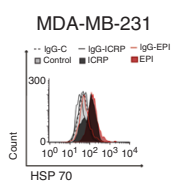

MDA-MB-231
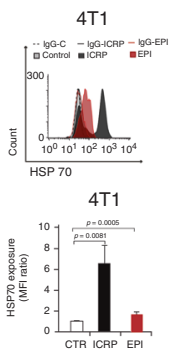

MCF-7

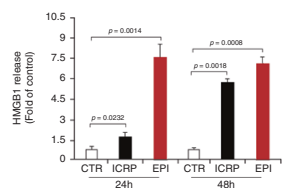

$4 \mathrm{~T} 1$

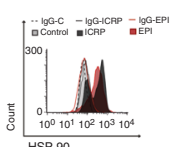

MCF-7

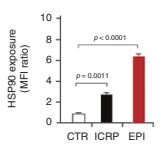

MDA-MB-231

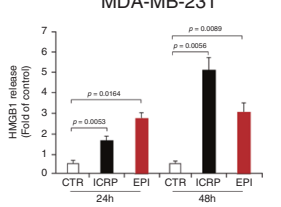

MDA-MB-231

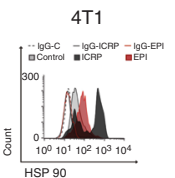

$4 \mathrm{~T} 1$

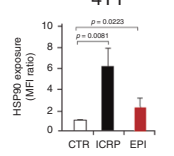

4T1

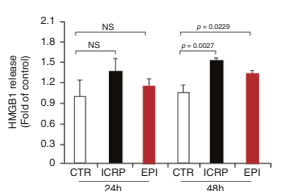

Fig. 2 IMMUNEPOTENT CRP causes elF2a phosphorylation and DAMP emission in MCF-7, MDA-MB-231 and 4T1 cells. a Representative FACS histograms of P-elF2 $\alpha$ staining (in grey) and IgG isotype antibodies (dotted) of cancer cells left untreated (negative control) or treated with ICRP CC ${ }_{50}$ for $18 \mathrm{~h}$ or $1 \mu \mathrm{M}$ Thaps for $2 \mathrm{~h}$ (positive control). Charts are the quantification of P-elF2 $\alpha$ staining in controls and cancer cells treated with ICRP or Thaps. b-d Representative FACS histograms of CRT (b), HSP70 (c) or HSP90 (d) exposure (filled histograms) and IgG isotype antibodies (open histograms) of cancer cells left untreated (negative control in grey) or treated with ICRP CC ${ }_{50}$ (in black), or EPI CC 50 (positive control in red) for $24 \mathrm{~h}$. Charts are the quantification of CRT (b), HSP70 (c) or HSP90 (d) exposure in cancer cells left untreated or treated with ICRP $\mathrm{CC}_{50}$ or EPI CC 50 for $24 \mathrm{~h}$. e Quantification of ATP release through bioluminescence detection in the supernatants of cancer cells in the absence (negative control) or presence of ICRP CC 50 or EPI CC 50 for $24 \mathrm{~h}$. $f$ Quantification of HMGB1 release assessed by ELISA in the supernatants of cancer cells in the absence (negative control) or presence of ICRP $\mathrm{CC}_{50}$ or EPI $\mathrm{CC}_{50}$ for $24 \mathrm{~h}$ and $48 \mathrm{~h}$. Graphs represent the means $( \pm S D)$ of triplicates of at least three independent experiments.

231 cells, and confirmed using MCF-7 cells, which are deficient in caspase 3 expression. ${ }^{22}$

Additionally, ICRP induced P-elF2a (ER stress biomarker) in the three cell lines. The capacity of many agents to induce ICD relies on their ability to trigger ROS production and ER stress, being these two cellular processes essential components that initiate the intracellular danger signalling pathways that dictate ICD. ${ }^{23,24}$

ER stress response and ROS production have been associated with the induction of autophagy. ${ }^{24,25}$ As we mentioned before, in this study, we proved that ICRP caused autophagosome formation in MCF-7, MDA-MB-231 and 4T1 cells, corresponding with the decrease in p62 levels observed after ICRP treatment, as p62 is itself degraded, when autophagy is induced. ${ }^{26}$ The induction of ROS production, ER stress and autophagy has been observed in other studies, for instance, Shikonin induces cell death and prosurvival autophagy in human melanoma cells via ROS-mediated ER stress. ${ }^{27}$ Furthermore, radiotherapy causes ROS generation, DNA damage, ER stress and autophagy in cancer cells. ${ }^{28}$ The increase in ROS, ER stress and autophagy has been associated with cancer therapies that are classified as ICD inducers. ${ }^{29,30}$

P-elF2a regularly antecedes chaperone protein exposure in the course of ICD; nonetheless, P-elF2 $a$ is not necessarily followed by CRT exposure, particularly when the ER stress response reestablishes cell homoeostasis; ${ }^{24,31}$ for this reason, we decided to evaluate P-elF2 $a$ after $18 \mathrm{~h}$ of treatment, and surface-exposed chaperones after $24 \mathrm{~h}$ of treatment with ICRP. Here, we demonstrated that ICRP induced P-elF2 $a$ and increased the "eat me signals" CRT, HSP70 and HSP90 on breast cancer cell surface, and also decreased the surface-associated "don't eat me" signal CD47. This constellation of surface signals then acts on phagocytic receptors of immune cells facilitating cellular engulfment. ${ }^{32}$ The increased exposure of CRT, HSP70 and HSP90 proteins on cell surface was also observed after EPI treatment, a well-known inducer of ICD in breast cancer cells, ${ }^{33}$ used here as positive control.

Higher levels of ATP release were observed after ICRP and EPI treatment in MCF-7 and MDA-MB-231 cells in comparison with 4T1 cells, this corresponds with previous studies in which it has been demonstrated that 4T1 is a p53-deficient cell line ${ }^{34}$ and ATP is produced at higher levels using oxidative phosphorylation in cells expressing p53 versus cells lacking p53. ${ }^{35}$ Besides, ICRP and EPI treatments triggered significant HMGB1 release in MCF-7 and MDA-MB-231, but partial HMGB1 release in 4T1 cells. This low ICRP-mediated HMGB1 release could be due to the exposure of cells to ICRP $\mathrm{CC}_{50}$ treatment, which was not sufficient for a significant release of $\mathrm{HMGB} 1$, as some agents induce the release of HMGB1 at $\mathrm{CC}_{100}$ but not $\mathrm{CC}_{50}{ }^{36}$ Furthermore, as HMGB1 release has been observed at late times in the course of $I C D,{ }^{37}$ we evaluated this parameter at $48 \mathrm{~h}$, and we found a significant HMGB1 release after ICRP and EPI treatment on the three cell lines.

Another drug classified as ICD inducer is the alkylating agent $\mathrm{CPA}_{i}{ }^{38,39}$ controversially, in our hands, this drug only triggered DAMP emission in MCF-7 cells but not in triple-negative MDA-MB231 and $4 \mathrm{~T} 1$ cells, this could be due to the fact that alkylating agents can induce NRF2 activation that blocks ER stress, ${ }^{40}$ one of the principal parameters related to ICD.

DAMP emission induced by ICRP was also observed in MCF-7 cells, which are deficient in caspase 3 expression, suggesting that these processes do not require caspase 3 activation to take place. Although caspase activation plays a key role during DAMP emission and the immunogenicity of the cell death induced by several cancer treatments, ${ }^{23,41,42}$ it has also been observed that a DAMP emission can be triggered in a caspase-independent fashion, for instance, Hyp-PDT-induced CRT exposure is caspase- 
a
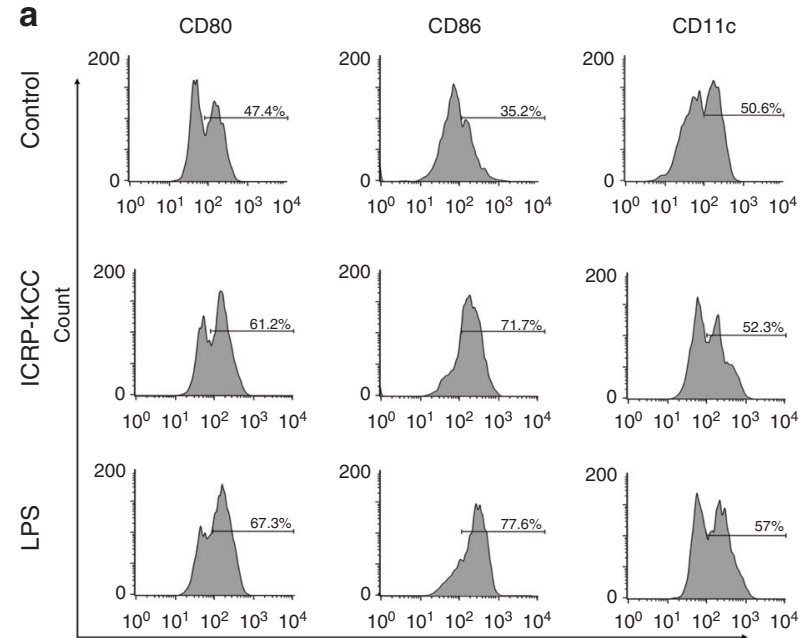

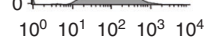
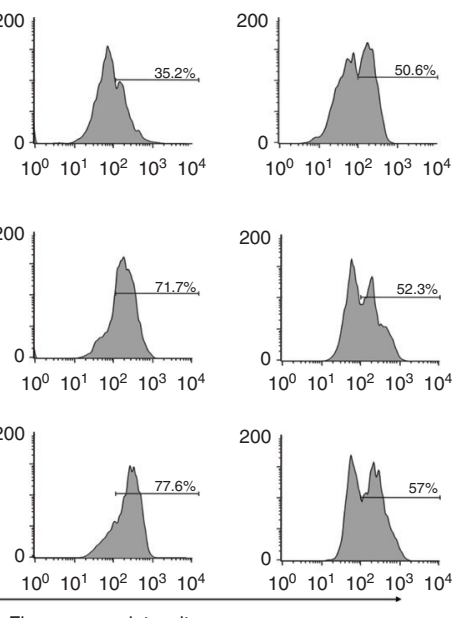

b

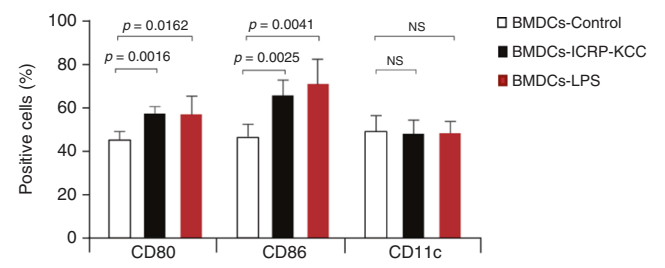

C
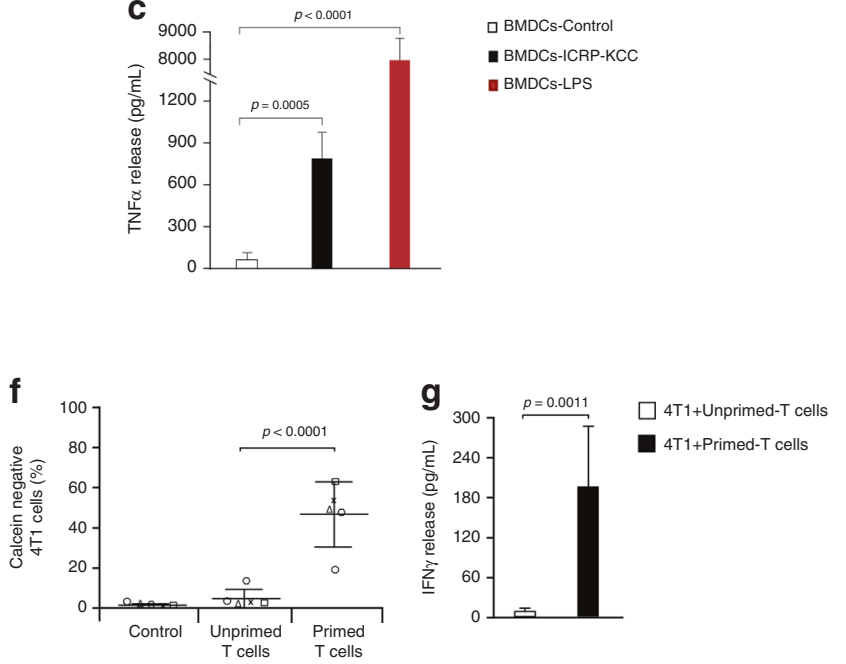

Fig. 3 ICRP-KCC triggers BMDC maturation and anticancer immune response. a Representative flow cytometry histograms showing the percentage of CD80+, CD86+ and CD11C+ BMDCs unstimulated (negative control), in co-culture ratio 1:3 with ICRP-treated 4T1 cells (ICRP$\mathrm{KCC}$ ) or stimulated with $1 \mu \mathrm{g} / \mathrm{mL}$ of LPS (positive control) during $24 \mathrm{~h}$. b BMDCs were treated as in (a) and the means ( \pm SD) obtained of five independent experiments were graphed. c Quantification of TNF- $\alpha$ concentration in supernatants of BMDCs treated as in (a). d, e Concentration of TNF- $\alpha$ (d) and IFN- $\gamma$ (e) in supernatants of unstimulated BMDCs (BMDC-Control) or stimulated with ICRP-KCC (BMDC-ICRP$\mathrm{KCC}$ ), in co-culture ratio 1:3 with T cells for $96 \mathrm{~h}$, expressed as the means ( $\pm \mathrm{SD}$ ) of five independent experiments. f Percentage of calceinnegative 4T1 cells left alone (Control) or after co-culture with unprimed T lymphocytes (previously co-cultured with BMDC-Control) or primed T lymphocytes (previously co-cultured with BMDC-ICRP-KCC) for $24 \mathrm{~h}$ (co-culture ratio 1:5). g Quantification of IFN- $\gamma$ concentration in supernatants of $4 \mathrm{~T} 1$ cells treated as in (f), expressed as the means $( \pm \mathrm{SD})$ of five independent experiments. $n=5$ mice per group.

independent, ${ }^{43}$ and chemotherapeutic agents can activate an alternative caspase-insensitive mechanism for secretion of ATP. ${ }^{44}$

Nevertheless, it has been demonstrated that the release/ exposure of all DAMPs is not determinant for immunogenic cell death; ${ }^{45}$ thus, we further evaluated ex vivo and in vivo the immunogenicity of the cell death induced by ICRP. Cancer-dying cells by ICD inducers promote DC maturation, which strongly activates anticancer immunity. According to current models, only few treatments induce intracellular signalling pathways that lead to a cancer cell death able to stimulate fully mature DCs, including cyclophosphamide, ${ }^{46} y$-irradiation, ${ }^{47}$ doxorubicin, oxaliplatin, ${ }^{48}$ bortezomib ${ }^{49}$ and a CD47 agonist peptide. ${ }^{50}$ Other therapies are only speculated to induce complete DC maturation, or use LPS, IFN type 1 or other stimulants in combination with tumour cell lysates (TCL) to promote DC maturation. ${ }^{29,46}$ In addition, some cancer treatments may cause semi-mature DCs, namely DCs that lack phenotypic maturation markers or cytokine release, and thereby are unable to efficiently prime T cells. ${ }^{51}$ Here, we demonstrated that ICRP-KCC obtained from ICRP-mediated 4T1 cell death induced maturation of BMDCs, which triggers a specific anticancer immune response against 4T1 cancer cells.

Furthermore, with the prophylactic tumour vaccination model, we demonstrated that ICRP-KCC activates the adaptive immune system in $90 \%$ BALB/c mice, leading to a long-term antitumour memory, which is desirable in cancer patients dealing with cancer recurrence. Usually, ICD inducers protect from $50 \%$ to $90 \%$ of individuals when used alone, without any type of adjuvants; such is the case of Hypericin-based photodynamic therapy $(87 \%),{ }^{43}$ mitoxantrone $(80 \%),{ }^{52}$ oxaliplatin $(80 \%)^{53}$ and nanosecond pulsed electric fields (50\%). ${ }^{54}$ Other treatments need two previous vaccinations to induce slower tumour growth in vaccinated mice ${ }^{55}$ or the use of combinational therapy to reach protection in $80 \%$ of the cases. ${ }^{56}$ Moreover, agents classified as ICD inducers have been studied using TCL-loaded dendritic cell vaccines, but not $\mathrm{TCL}$, and after several vaccine boosting, they reach up to $70 \%$ of survival. ${ }^{29}$

To test the potential of ICRP to trigger ICD on breast cancer cells in contrast to other well-known ICD inducers, we compared ICRP treatment with EPI and CPA (two drugs classified as ICD inducers ${ }^{33,38,39}$ ) in prophylactic vaccination assays. We found that whereas EPI-KCC vaccination protected $70 \%$ of individuals, CPAKCC vaccination only protected $20 \%$ of individuals. These results are consistent with the observation of higher DAMP emission triggered by ICRP as compared to EPI, and the absence of DAMP emission after CPA treatment in $4 \mathrm{~T} 1$ cells. Our results highlight the importance of evaluating the immunogenicity of the cell death provoked by ICD inducers in different biochemical contexts, as the immune effect of ICD drugs, such as CPA, can differ between cancer models.

It is known that T-cell responses generally peak $\sim 1-4$ days after a second antigen stimulation. ${ }^{57,58}$ Here, we analysed tumour-draining lymph nodes after three days of tumour rechallenge and observed a follicular lymphoid hyperplasia in ICRP-KCC mice, which is associated with immunological memory; additionally, we observed an increase of mature DCs in ICRP-KCC mice in comparison to the naive group. Several studies have demonstrated that effector 

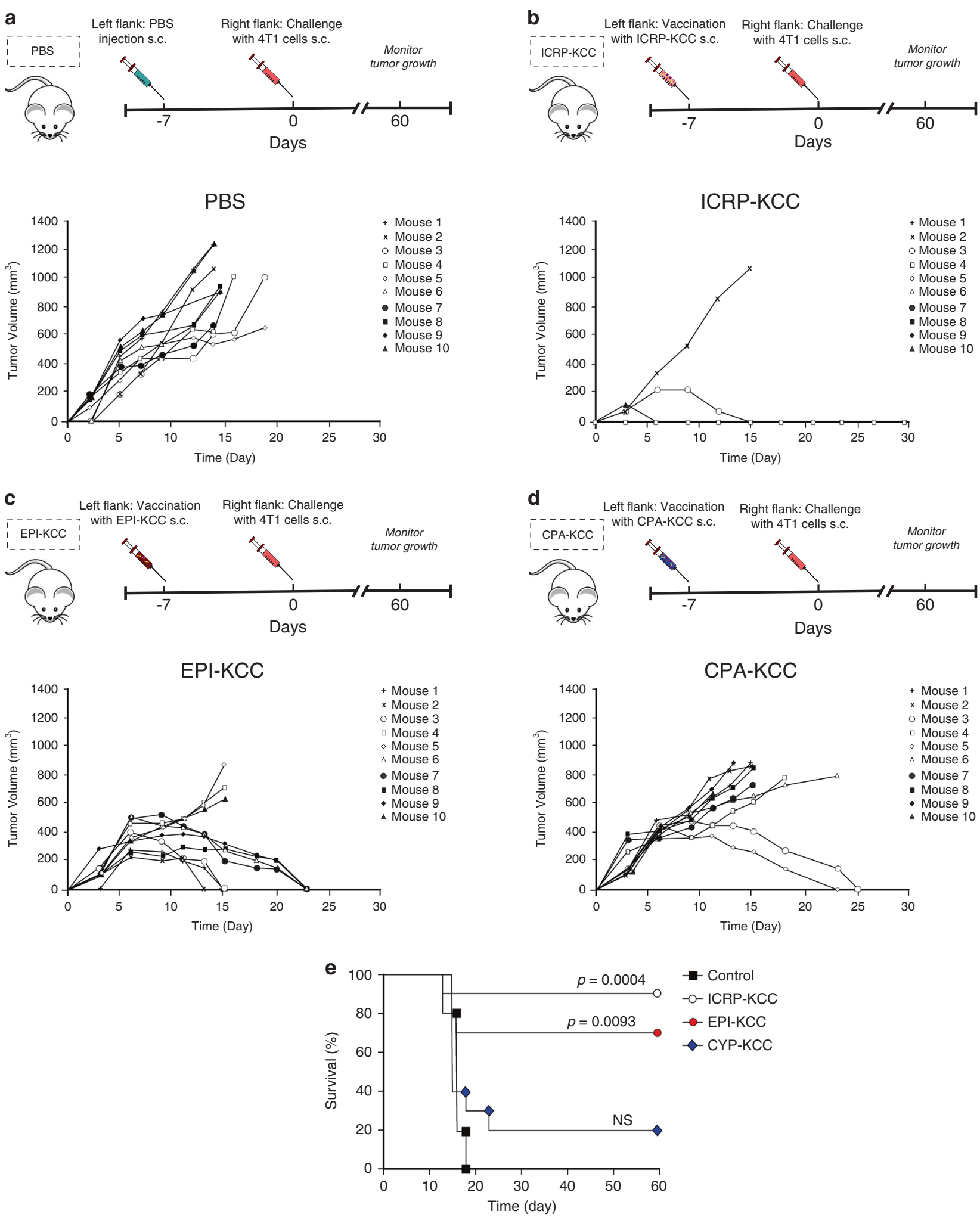

Fig. 4 Prophylactic vaccination with ICRP-KCC prevents tumour establishment in BALB/c mice. a-d Mice were inoculated s.C. with PBS, $1.5 \times 10^{6}$ ICRP-killed 4T1 cells (ICRP-KCC), $1.5 \times 10^{6}$ EPI-killed 4T1 cells (EPI-KCC) or $1.5 \times 10^{6}$ CPA-killed 4T1 cells (CPA-KCC) on the left flank side. On day 7 after vaccination, mice were challenged s.c. on the opposite flank with $5 \times 10^{5}$ viable 4T1 cells. Tumour growth on the challenge site was evaluated for up to 60 days after the challenge. Tumour volume on the challenge site of unvaccinated mice (PBS) (a) or vaccinated with ICRP-KCC (b), EPI-KCC (c) or CPA-KCC (d). Each line represents one mouse. e Kaplan-Meier graph with the percentage of survival in mice treated as in (a-d) ( $n=10$ mice per group). 
a

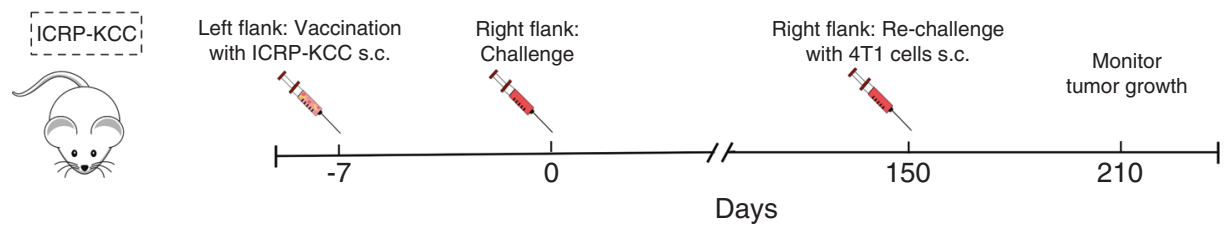

b

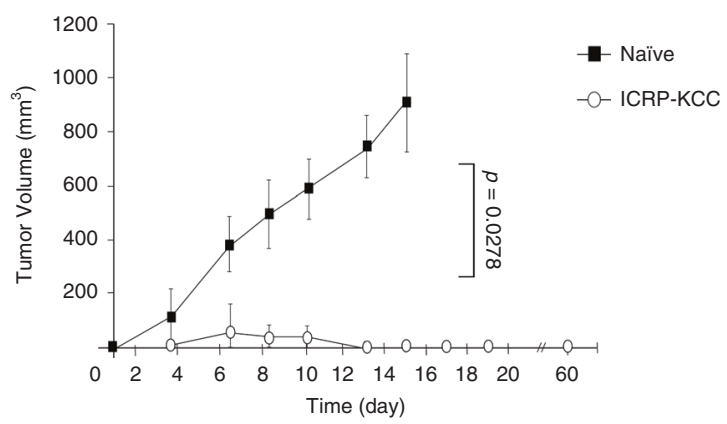

d

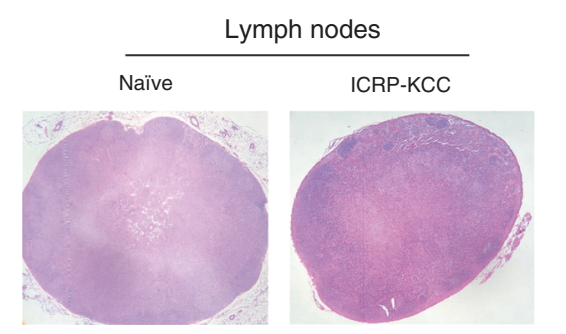

f

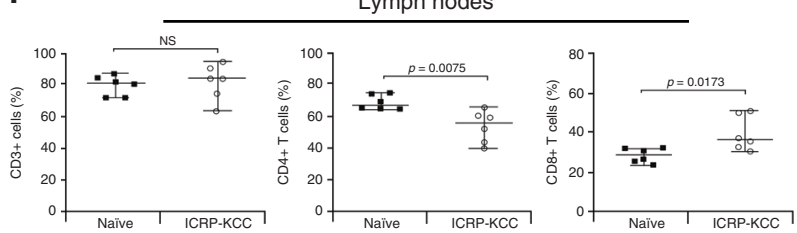

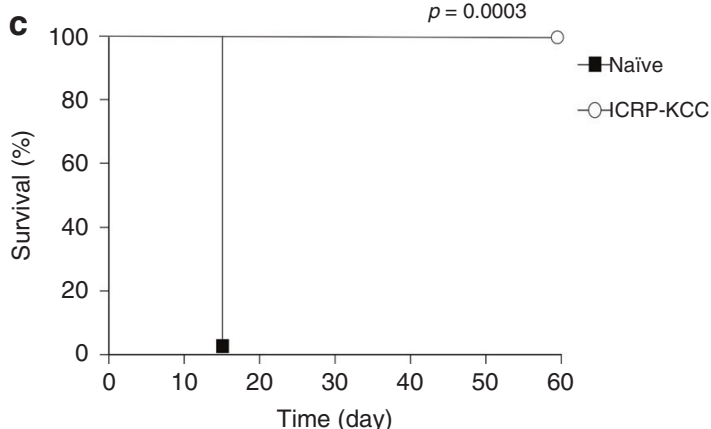

e

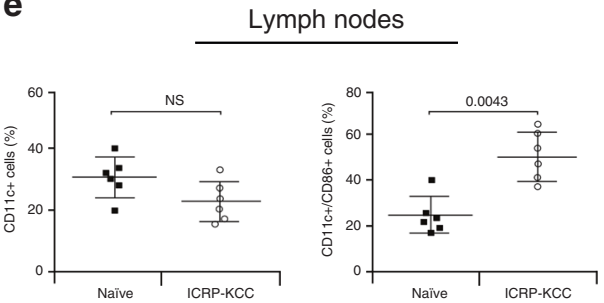

g Peripheral blood

h

Tumor re-challnege site

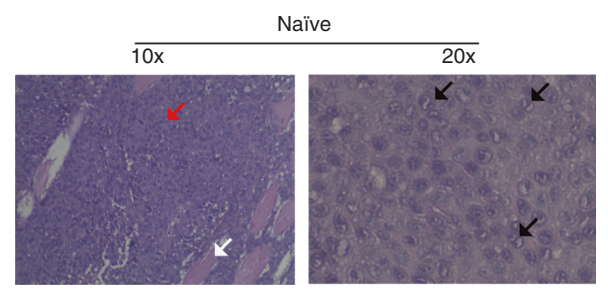

i

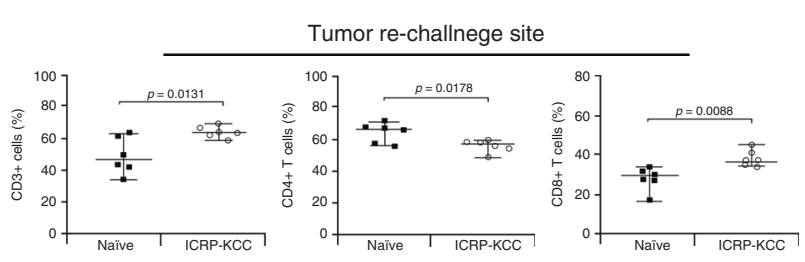

memory $T$ cells potentiate the maturation of DCs, and in addition to $T$ cells, BCR signalling is sufficient for memory B cells to induce complete activation of DCs. ${ }^{59}$

We also observed an increase of CD8 $+T$ cells over CD4 $+T$ cells in the TDLNs, peripheral blood and tumour rechallenge site of immunised mice; these results correspond with the observations that in the same host, memory assessments result in robust CD8+ $\mathrm{T}$-cell responses, but poor boosting of CD4+ T-cell recall

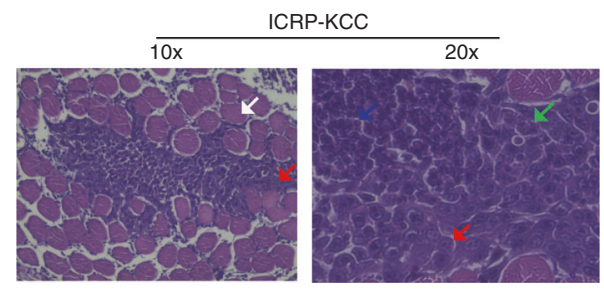

j

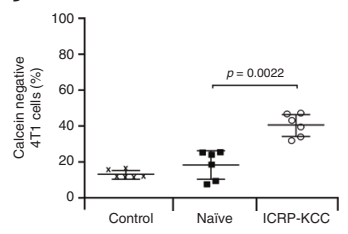

k

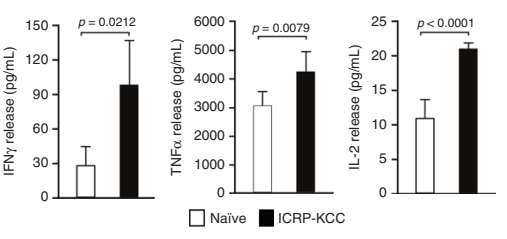

responses, $^{60}$ which is correlated with the demonstration that CD4+ memory cells proliferated for a shorter period of time than CD4+ naive cells because of their cytokine profile. ${ }^{61}$

Finally, we observed a tumour-specific cytotoxicity by splenocytes from immunised mice, whereas no cytotoxicity was observed in the co-culture of 4T1 with splenocytes from naive mice, indicating the activation of a rapid immune response triggered by the antitumour memory establishment. This 
Fig. 5 ICRP-KCC prophylactic vaccination induces long-term antitumour memory, modulates tumour establishment, DC maturation, Tcell distribution and splenocyte-tumour-specific cytotoxicity after tumour rechallenge. a Mice in remission after ICRP-KCC prophylactic vaccination were rechallenged s.c. with $5 \times 10^{5}$ viable 4 T1 cells after 150 days of prophylactic vaccination. Tumour growth on the challenge site was evaluated for up to 60 days after rechallenge. b Tumour volume on the challenge site of naive mice (black square, $n=9$ mice) or mice in remission after a previous $1.5 \times 10^{6}$ ICRP-KCC vaccination (white circle, $n=9$ mice). c Kaplan-Meier graph with the percentage of survival of mice treated as in (c). d, k Naive mice $(n=6)$ and mice in remission after ICRP-KCC prophylactic vaccination $(n=6)$ were challenged/ rechallenged s.c. with $5 \times 10^{5}$ viable $4 \mathrm{~T} 1$ cells. Three days later, tumour-draining lymph nodes, peripheral blood, the tumour rechallenge site and spleen were obtained. d Histology from lymph nodes of naive and ICRP-KCC mice stained with H\&E. e Percentage of CD11C- and CD86positive cells in TDLNs of naive and ICRP-KCC mice. f, $\mathbf{g}$ Proportion of CD3-, CD4- and CD8-positive cells in TDLNs (f) and peripheral blood (g) of naive and ICRP-KCC mice. h Histology from tumour rechallenge sites of naive and ICRP-KCC mice stained with H\&E. Normal tissue (white arrows), tumour cells (red arrows), mitotic cells (black arrows), lymphocytes (blue arrows) and polymorphonuclear cells (green arrows). $\mathbf{i}$ Proportion of CD3-, CD4- and CD8-positive cells in tumour rechallenge sites of naive and ICRP-KCC mice. $\mathbf{j}$ Percentage of calcein-negative $4 \mathrm{~T} 1$ cells left alone (Control), or co-cultured with splenocytes from naive or ICRP-KCC mice for $24 \mathrm{~h}$ (co-culture ratio 1:40). $\mathbf{k}$ Quantification of IFN- $\gamma$, TNF- $\alpha$ and IL-2 concentration in supernatants of co-cultures obtained as in (j), expressed as the means ( \pm SD) of three independent experiments ( $n=6$ mice per group).

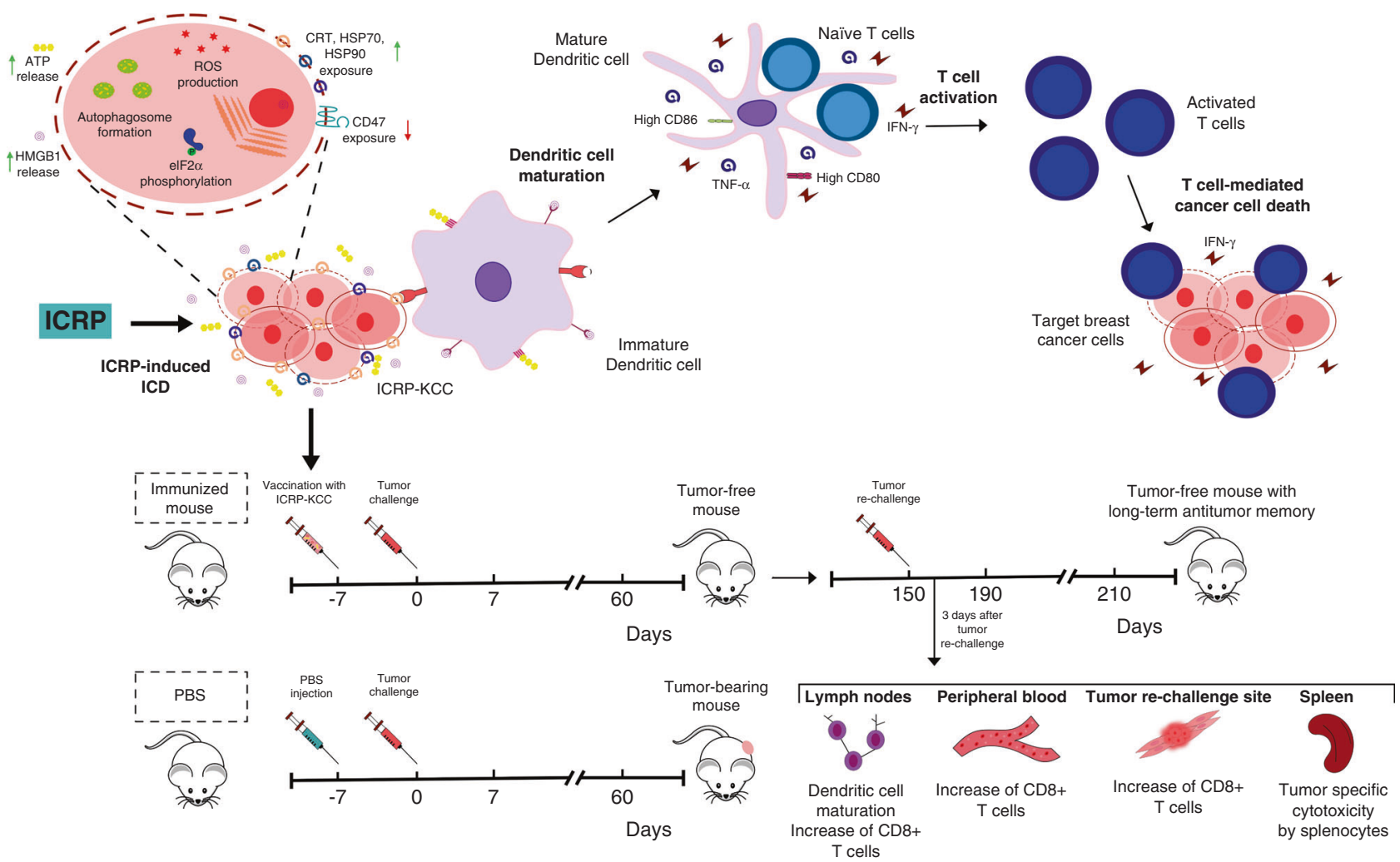

Fig. 6 Schematic depiction of IMMUNEPOTENT CRP-induced immunogenic cell death in breast cancer cells. IMMUNEPOTENT CRP induces ROS production, autophagosome formation and elF $2 \alpha$ phosphorylation in breast cancer cell lines leading to DAMP release. Neoantigens and the release of DAMPs promote DC maturation, which triggers T-cell activation to induce cancer cytotoxicity. Moreover, ICRP-KCC prophylactic vaccination prevented tumour establishment and induces long-term antitumour memory in BALB/c mice; this protection involves an increase of DC maturation in lymph nodes, CD8+ T cells in lymph nodes, peripheral blood and tumour rechallenge site, as well as tumour-specific cytotoxicity by splenocytes. ROS, reactive oxygen species; ER, endoplasmic reticulum; CRT, calreticulin; HSP70, 70-kDa heat shock protein; HSP90, 90-kDa heat shock protein; CD47, Cluster of Differentiation 47; HMGB1, high-mobility group box 1; ATP, adenosine triphosphate; TNF- $\alpha$, tumour necrosis factor alpha; IFN- $\gamma$, interferon gamma.

evaluation corresponds with our ex vivo assessment where we observed an increase in Th1-type cytokines, which are associated with the generation of cytotoxic responses. ${ }^{62}$

The results in this work are supported by the recent demonstration that breast tumour-bearing mice treated with ICRP present a decrease in tumour volume and increase in survival in comparison with untreated mice. ${ }^{63}$ Also, within the tumour, ICRP treatment decreased PD-L1, IDO and Gal-3 expression, IL-6, IL-10 and MCP-1 levels, and increased IFN- $\gamma$ and IL-12 levels. Moreover, ICRP treatment increased CD8 $+\mathrm{T}$ cells, memory $\mathrm{T}$ cells and innate effector cells in peripheral blood, where an increase was also observed in IFN- $\gamma$ and IL-12 levels, ${ }^{63}$ indicating that these findings could be due to ICD induction in the tumour of these mice.
In conclusion, IMMUNEPOTENT CRP triggers loss of mitochondrial membrane potential, pro-survival autophagosome formation, elF2a phosphorylation and caspase-independent but ROSdependent cell death in breast cancer cells; these intracellular signalling pathways lead to alterations in the composition of the plasma membrane of dying cells (increased CRT, HSP70 and HSP90 exposure and decreased CD47 exposure), as well in their microenvironment (release of ATP and HMGB1), which stimulates DC maturation, priming of $T$ cells, promoting an antitumour immune response ex vivo and in vivo and leading to a long-term antitumour memory (Fig. 6). Overall, our results show that ICRP may have the capacity to turn breast cancer cells into potential vaccines in vivo. 


\section{ACKNOWLEDGEMENTS}

We thank Laboratorio de Inmunología y Virología from Facultad de Ciencias Biologicas of the Universidad Autonoma de Nuevo Leon for the facilities provided to achieve this work. ARR and KMCR thank CONACyT for scholarship. We thank Ana Luisa Rivera-Lazarin, Rodolfo Mendoza-Reveles and Martin Herrick Ramón Kane for technical help.

\section{AUTHOR CONTRIBUTIONS}

A.R.R. and K.M.R.C. designed and performed all the in vitro, ex vivo and in vivo experiments. K.M.C.R. established the ex vivo and in vivo models. A.C.M.T. directed, conceived and supervised the project. A.R.R. and A.C.M.T. wrote the paper with support of K.M.C.R. A.R.R., K.M.C.R. and A.C.M.T. prepared the figures. A.R.R., K.M.C.R., A.C.M.T. and C.R.P. designed experiments, performed statistical analysis, analysed and interpreted data and read and approved the final paper.

\section{ADDITIONAL INFORMATION}

Ethics approval and consent to participate The Animal Research and Welfare Ethics Committee (CEIBA) of the School of Biological Sciences approved this study: CEIBA-2019/20-006. All experiments were conducted according to Mexican regulation NOM-062-ZOO-1999.

Consent to publish Not applicable.

Data availability The datasets that support the findings of this study are available from the corresponding author on reasonable request.

Competing interests The authors declare no competing interests.

Funding information This work was supported by Longeveden, SA de CV, the Laboratorio de Inmunología y Virología and PAICYT of the Universidad Autonoma de Nuevo Leon grant CN1220-20 to ACMT.

Supplementary information is available for this paper at https://doi.org/10.1038/ s41416-020-01256-y.

Note This work is published under the standard license to publish agreement. After 12 months the work will become freely available and the license terms will switch to a Creative Commons Attribution 4.0 International (CC BY 4.0).

Publisher's note Springer Nature remains neutral with regard to jurisdictional claims in published maps and institutional affiliations.

\section{REFERENCES}

1. Siegel, R. L., Miller, K. D. \& Jemal, A. Cancer statistics. CA Cancer J. Clin. 69, 7-34 (2019).

2. Richman, J. \& Dowsett, M. Beyond 5 years: enduring risk of recurrence in oestrogen receptor-positive breast cancer. Nat. Rev. Clin. Oncol. 16, 296-311 (2019).

3. Pederzini, A. Immunotherapy in breast cancer. Panminerva Med 15, 435-436 (1973).

4. Kroemer, G., Galluzzi, L., Kepp, O. \& Zitvogel, L. Immunogenic cell death in cancer therapy. Annu Rev. Immunol. 31, 51-72 (2013).

5. Garg, A. D., More, S., Rufo, N., Mece, O., Sassano, M. L., Agostinis, P. et al. Trial watch: immunogenic cell death induction by anticancer chemotherapeutics. Oncolmmunology https://doi.org/10.1080/2162402X.2017.1386829 (2017).

6. Galluzzi, L., Senovilla, L., Zitvogel, L. \& Kroemer, G. The secret ally: Immunostimulation by anticancer drugs. Nat. Rev. Drug Discov. 11, 215-233 (2012).

7. Ladoire, S., Mignot, G., Dabakuyo, S., Arnould, L., Apetoh, L., Rébé, C. et al. In situ immune response after neoadjuvant chemotherapy for breast cancer predicts survival. J. Pathol. 224, 389-400 (2011).

8. Franco-Molina, M. A., Mendoza-Gamboa, E., Zapata-Benavides, P., Castillo-Tello, P., Isaza-Brando, C. E., Zamora-Avila, D. et al. Antiangiogenic and antitumor effects of IMMUNEPOTENT CRP in murine melanoma. Immunopharmacol. Immunotoxicol. 32, 637-646 (2010).

9. Martínez-Torres, A. C., Reyes-Ruiz, A., Benítez-Londoño, M., Franco-Molina, M. A. \& Rodríguez-Padilla, C. IMMUNEPOTENT CRP induces cell cycle arrest and caspaseindependent regulated cell death in HeLa cells through reactive oxygen species production. BMC Cancer 18, 13 (2018).

10. Martinez-Torres, A. C., Gomez-Morales, L., Martinez-Loria, A. B., Uscanga-Palomeque, A. C., Vazquez-Guillen, J. M. \& Rodriguez-Padilla, C. Cytotoxic activity of
IMMUNEPOTENT CRP against non-small cell lung cancer cell lines. PeerJ 7, e7759 (2019).

11. Lorenzo-Anota, H. Y., Martínez-Torres, A. C., Scott-Algara, D., Tamez-Guerra, R. S. \& Rodríguez-Padilla, C. Bovine Dialyzable Leukocyte Extract IMMUNEPOTENT-CRP Induces Selective ROS-Dependent Apoptosis in T-Acute Lymphoblastic Leukemia Cell Lines. J. Oncol. https://doi.org/10.1155/2020/1598503 (2020).

12. Rodríguez-Salazar, M. D. C., Franco-Molina, M. A., Mendoza-Gamboa, E., MartínezTorres, A. C., Zapata-Benavides, P., López-González, J. S. et al. The novel immunomodulator IMMUNEPOTENT CRP combined with chemotherapy agent increased the rate of immunogenic cell death and prevented melanoma growth. Oncol. Lett. 14, 844-852 (2017).

13. Martínez-Torres, A. C., Reyes-Ruiz, A., Calvillo-Rodriguez, K. M., Alvarez-Valadez, K. M., Uscanga-Palomeque, A. C., Tamez-Guerra, R. S. et al. IMMUNEPOTENT CRP induces DAMPS release and ROS-dependent autophagosome formation in HeLa and MCF-7 cells. BMC Cancer 20, 647 (2020).

14. Hou, W., Zhang, Q., Yan, Z., Chen, R., Zeh, H. J., Kang, R. et al. Strange attractors: DAMPs and autophagy link tumor cell death and immunity. Cell Death Dis. 4, e966 (2013).

15. Zhang, Q., Kang, R., Zeh, H. J., Lotze, M. T. \& Tang, D. DAMPs and autophagy: cellular adaptation to injury and unscheduled cell death. Autophagy 9, 451-458 (2013).

16. Kilkenny, C., Browne, W. J., Cuthill, I. C., Emerson, M. \& Altman, D. G. Improving bioscience research reporting: the arrive guidelines for reporting animal research. PLoS Biol. 8, e1000412 (2010).

17. Meurer, S. K., Neß, M., Weiskirchen, S., Kim, P., Tag, C. G., Kauffmann, M. et al. Isolation of mature (Peritoneum-Derived) mast cells and immature (bone marrow-derived) mast cell precursors from mice. PLOS ONE 11, e0158104 (2016).

18. Kepp, O., Tartour, E., Vitale, I., Vacchelli, E., Adjemian, S., Agostinis, P. et al. Consensus guidelines for the detection of immunogenic cell death. Oncolmmunology 3, 9 (2014).

19. Martínez-Torres, A. C., Zarate-Triviño, D. G., Lorenzo-Anota, H. Y., Ávila-Ávila, A., Rodríguez-Abrego, C. \& Rodríguez-Padilla, C. Chitosan gold nanoparticles induce cell death in hela and MCF-7 cells through reactive oxygen species production. Int J. Nanomed. 13, 3235-3250 (2018).

20. Martínez-Torres, A. C., Lorenzo-Anota, H. Y., García-Juárez, Martín, G., Zarate-Triviño, D. G. \& Rodríguez-Padilla, C. Chitosan gold nanoparticles induce different ROS-dependent cell death modalities in leukemic cells. Int J. Nanomed. 14, 7173-7190 (2019).

21. Das, C. K., Mandal, M. \& Kögel, D. Pro-survival autophagy and cancer cell resistance to therapy. Cancer Metastasis Rev. 37, 749-766 (2018).

22. Huang, Q., Li, F., Liu, X., Li, W., Shi, W., Liu, F. F. et al. Caspase 3-mediated stimulation of tumor cell repopulation during cancer radiotherapy. Nat. Med 17, 860-866 (2011).

23. Krysko, D. V., Garg, A. D., Kaczmarek, A., Krysko, O., Agostinis, P. \& Vandenabeele, P. Immunogenic cell death and DAMPs in cancer therapy. Nat. Rev. Cancer 12, 860-875 (2012).

24. Kepp, O., Semeraro, M., Bravo-San Pedro, J. M., Bloy, N., Buqué, A., Huang, X. et al. EIF2a phosphorylation as a biomarker of immunogenic cell death. Semin. Cancer Biol. 33, 86-92 (2015).

25. Sica, V., Galluzzi, L., Bravo-San Pedro, J. M., Izzo, V., Maiuri, M. C. \& Kroemer, G. Organelle-specific initiation of autophagy. Mol. Cell 59, 522-539 (2015).

26. Yoshii, S. R. \& Mizushima, N. Monitoring and measuring autophagy. Int. J. Mol. Sci. 18, 1865 (2017).

27. Liu, Y., Kang, X., Niu, G., He, S., Zhang, T., Bai, Y. et al. Shikonin induces apoptosis and prosurvival autophagy in human melanoma A375 cells via ROS-mediated ER stress and p38 pathways. Artif. Cells, Nanomed., Biotechnol. 47, 626-635 (2019).

28. Kim, W., Lee, S., Seo, D., Kim, K., Kim, E. et al. Cellular stress responses in radiotherapy. Cells 8, 1105 (2019).

29. Chen, H. M., Wang, P. H., Chen, S. S., Wen, C. C., Chen, Y. H., Yang, W. C. et al. Shikonin induces immunogenic cell death in tumor cells and enhances dendritic cell-based cancer vaccine. Cancer Immunol. Immunother. 61, 1989-2002 (2012).

30. Obeid, M., Panaretakis, T., Joza, N., Tufi, R., Tesniere, A., van Endert, P. et al. Calreticulin exposure is required for the immunogenicity of $\gamma$-irradiation and UVC light-induced apoptosis. Cell Death Differ. 14, 1848-1850 (2007).

31. Xu, C., Bailly-Maitre, B. \& Reed, J. C. Endoplasmic reticulum stress: Cell life and death decisions. J. Clin. Investig. 115, 2656-2664 (2005).

32. Garg, A. D., Romano, E., Rufo, N. \& Agostinis, P. Immunogenic versus tolerogenic phagocytosis during anticancer therapy: mechanisms and clinical translation. Cell Death Differ. 23, 938-951 (2016).

33. Li, L., Li, Y., Yang, C. H., Radford, D. C., Wang, J., Janát-Amsbury, M. et al. Inhibition of immunosuppressive tumors by polymer-assisted inductions of immunogenic cell death and multivalent PD-L1 crosslinking. Adv. Funct. Mater. 30, 1-13 (2020).

34. Sang, H., Pisarev, V. M., Chavez, J., Robinson, S., Guo, Y., Hatcher, L. et al. Murine mammary adenocarcinoma cells transfected with p53 and/or Flt3L induce antitumor immune responses. Cancer Gene Ther. 12, 427-437 (2005). 
35. Puzio-Kuter, A. M. The role of p53 in metabolic regulation. Genes Cancer 2, 385-391 (2011).

36. Uscanga-Palomeque, A. C., Calvillo-Rodríguez, K. M., Gómez-Morales, L., Lardé, E., Denèfle, T., Caballero-Hernández, D. et al. CD47 agonist peptide PKHB1 induces immunogenic cell death in T-cell acute lymphoblastic leukemia cells. Cancer Sci. 110, 256-268 (2019).

37. Ocadlikova, D., Lecciso, M., Isidori, A., Loscocco, F., Visani, G., Amadori, S. et al. Chemotherapy-induced tumor cell death at the crossroads between immunogenicity and immunotolerance: focus on acute myeloid leukemia. Front Oncol. 9, 1-10 (2019).

38. Wu, J. \& Waxman, D. J. Immunogenic chemotherapy: Dose and schedule dependence and combination with immunotherapy. Cancer Lett. 419, 210-221 (2018).

39. Rossi, A., Lucarini, V., Macchia, I., Sestili, P., Buccione, C., Donati, S. et al. Tumorintrinsic or drug-induced immunogenicity dictates the therapeutic success of the PD1/PDL axis blockade. Cells 9, 1-21 (2020).

40. Zanotto-filho, A., Masamsetti, V. P., Loranc, E., Tonapi, S. S., Bernard, X., Bishop, A. J. R. et al. Alkylating agent induced NRF2 blocks endoplasmic reticulum stressmediated apoptosis via control of glutathione pools and protein thiol homeostasis. Mol. Cancer Ther. 15, 3000-3014 (2017).

41. Yoon S., Park S. J., Han J. H., Kang J. H., Kim J. H., Lee J., et al. Caspase-dependent cell death-associated release of nucleosome and damage-associated molecular patterns. Cell Death Dis. https://doi.org/10.1038/cddis.2014.450 (2014).

42. Casares, N., Pequignot, M. O., Tesniere, A., Ghiringhelli, F., Roux, S., Chaput, N. et al. Caspase-dependent immunogenicity of doxorubicin-induced tumor cell death. J. Exp. Med. 202, 1691-1701 (2005).

43. Garg, A. D., Krysko, D. V., Verfaillie, T., Kaczmarek, A., Ferreira, G. B., Marysael, T. et al. A novel pathway combining calreticulin exposure and ATP secretion in immunogenic cancer cell death. EMBO J. 31, 1062-1079 (2012).

44. Boyd-Tressler, A., Penuela, S., Laird, D. W. \& Dubyak, G. R. Chemotherapeutic drugs induce ATP release via caspase-gated pannexin-1 channels and a caspase/ pannexin-1-independent mechanism. J. Biol. Chem. 289, 27246-27263 (2014)

45. Garg, A. D., Dudek, A. M., Ferreira, G. B., Verfaillie, T., Vandenabeele, P., Krysko, D. V. et al. ROS-induced autophagy in cancer cells assists in evasion from determinants of immunogenic cell death. Autophagy 9, 1292-1307 (2013).

46. Schiavoni, G., Sistigu, A., Valentini, M., Mattei, F., Sestili, P., Spadaro, F. et al. Cyclophosphamide synergizes with type I interferons through systemic dendritic cell reactivation and induction of immunogenic tumor apoptosis. Cancer Res. 71, 768-778 (2011).

47. Kim, S. K., Yun, C. H. \& Han, S. H. Enhanced anti-cancer activity of human dendritic cells sensitized with gamma-irradiation-induced apoptotic colon cancer cells. Cancer Lett. 335, 278-288 (2013).

48. Ghiringhelli, F., Apetoh, L., Tesniere, A., Aymeric, L., Ma, Y., Ortiz, C. et al. Activation of the NLRP3 inflammasome in dendritic cells induces IL-1B-dependent adaptive immunity against tumors. Nat. Med. 15, 1170-1178 (2009).

49. Cirone M., Di Renzo L., Lotti L. V., Conte V., Trivedi P., Santarelli R. et al. Primary effusion lymphoma cell death induced by bortezomib and AG 490 activates dendritic cells through CD91. PLoS ONE https://doi.org/10.1371/journal. pone.0031732 (2012).

50. Martínez-Torres A. C., Calvillo-Rodríguez K. M., Uscanga-Palomeque A. C., GómezMorales L., Mendoza-Reveles R., Caballero-Hernández D. et al. PKHB1 tumor cell lysate induces antitumor immune system stimulation and tumor regression in syngeneic mice with tumoral T lymphoblasts. J. Oncol. https://doi.org/10.1155/ 2019/9852361 (2019).

51. Dudek, A. M., Martin, S., Garg, A. D. \& Agostinis, P. Immature, semi-mature, and fully mature dendritic cells: Toward a DC-cancer cells interface that augments anticancer immunity. Front. Immunol. 4, 438 (2013).

52. Menger L., Vacchelli E., Adjemian S., Martins I., Ma Y., Shen S., et al. Cardiac glycosides exert anticancer effects by inducing immunogenic cell death. Sci Transl. Med. https://doi.org/10.1126/scitranslmed.3003807 (2012).

53. Tesniere, A., Schlemmer, F., Boige, V., Kepp, O., Martins, I., Ghiringhelli, F. et al. Immunogenic death of colon cancer cells treated with oxaliplatin. Oncogene 29, 482-491 (2010)

54. Rossi, A., Pakhomova, O. N., Mollica, P. A., Casciola, M., Mangalanathan, U., Pakhomov, A. G. et al. Nanosecond pulsed electric fields induce endoplasmic reticulum stress accompanied by immunogenic cell death in murine models of lymphoma and colorectal cancer. Cancers 11, 2034 (2019).

55. Qin, J., Kunda, N., Qiao, G., Calata, J. F., Pardiwala, K., Prabhakar, B. S. et al. Colon cancer cell treatment with rose bengal generates a protective immune response via immunogenic cell death. Cell Death Dis. 8, e2584 (2017).

56. Liu, P., Zhao, L., Pol, J., Levesque, S., Petrazzuolo, A., Pfirschke, C. et al. Crizotinibinduced immunogenic cell death in non-small cell lung cancer. Nat. Commun. 10, 1486 (2019).

57. Pennock, N. D., White, J. T., Cross, E. W., Cheney, E. E., Tamburini, B. A. \& Kedl, R. M. T cell responses: naïve to memory and everything in between. Adv. Physiol. Educ. 37, 273-283 (2013).

58. Punt J., Stranford S. A., Jones P. P. \& Owen J. A. (eds). Kuby Immunology, 8th edn. (McGraw-Hill Education, New York, USA, 2019).

59. Maddur, M. S., Kaveri, S. V. \& Bayry, J. Induction of human dendritic cell maturation by naïve and memory B-cell subsets requires different activation stimuli. Cell. Mol. Immunol. 15, 1074-1076 (2018).

60. Ravkov, E. V. \& Williams, M. A. The magnitude of CD4+ T cell recall responses is controlled by the duration of the secondary stimulus. J. Immunol. 183, 2382-2389 (2009).

61. MacLeod, M. K. L., McKee, A., Crawford, F., White, J., Kappler, J. \& Marrack, P. CD4 memory $T$ cells divide poorly in response to antigen because of their cytokine profile. Proc. Natl Acad. Sci. USA 105, 14521-14526 (2008).

62. Berger, A. Science commentary: Th1 and Th2 responses: what are they? Br. Med. J. 321, 424 (2000).

63. Santana-Krímskaya, S. E., Franco-Molina, M. A., Zárate-Triviño, D. G., Prado-García, H., Zapata-Benavides, P., Torres-del-Muro, F. et al. IMMUNEPOTENT CRP plus doxorubicin/cyclophosphamide chemotherapy remodel the tumor microenvironment in an air pouch triple-negative breast cancer murine model. Biomed. Pharmacother. https://doi.org/10.1016/j.biopha.2020.110062 (2020). 